\section{Corps}

leers

Waterways Experiment

\section{US-CE-C PROPERTY OF THE} UNITED STATES GOVERNMENT

\title{
Truckee River Sedimentation Study
}

\author{
by Brad R. Hall, William A. Thomas \\ Hydraulics Laboratory
}

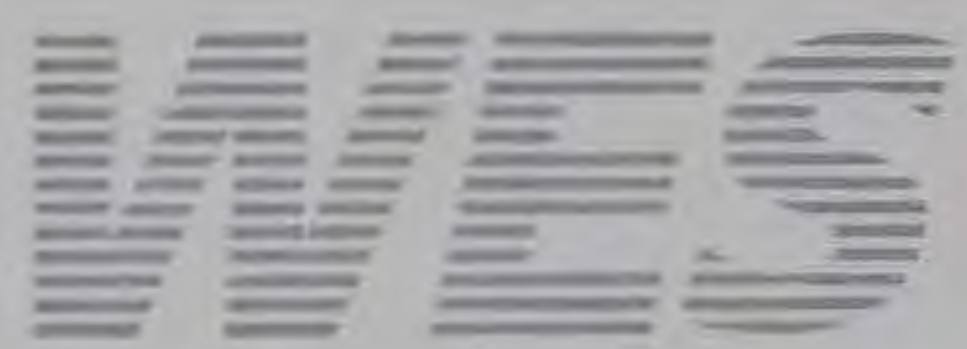

Approved For Public Release; Distribution Is Unlimited

RESEARCH LIBRARY

US ARMY ENGINEER WATERWAYS

EXPERIMENT STATION

VICKSBURG, MISSISSIPPI

Prepared for U.S. Army Engineer District, Sacramento 


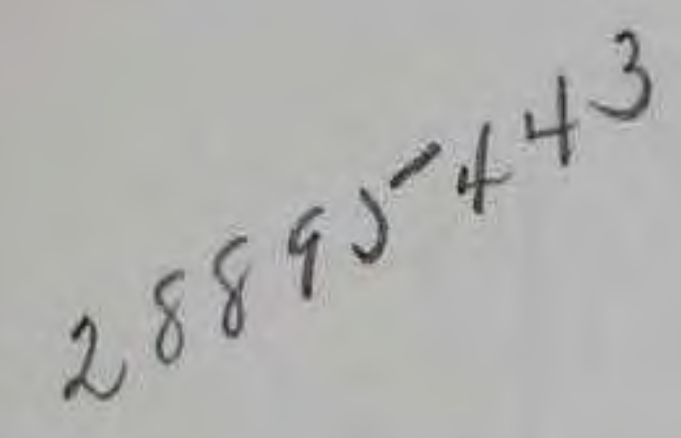

Technical Report HL-93-13

September 1993

\section{Truckee River Sedimentation Study}

by Brad R. Hall, William A. Thomas

Hydraulics Laboratory

U.S. Army Corps of Engineers

Waterways Experiment Station

3909 Halls Ferry Road

Vicksburg, MS 39180-6199

Final report

Approved for public release; distribution is unlimited

Prepared for U.S. Army Engineer District, Sacramento $1325 \mathrm{~J}$ Street

Sacramento, CA 95814-2922 


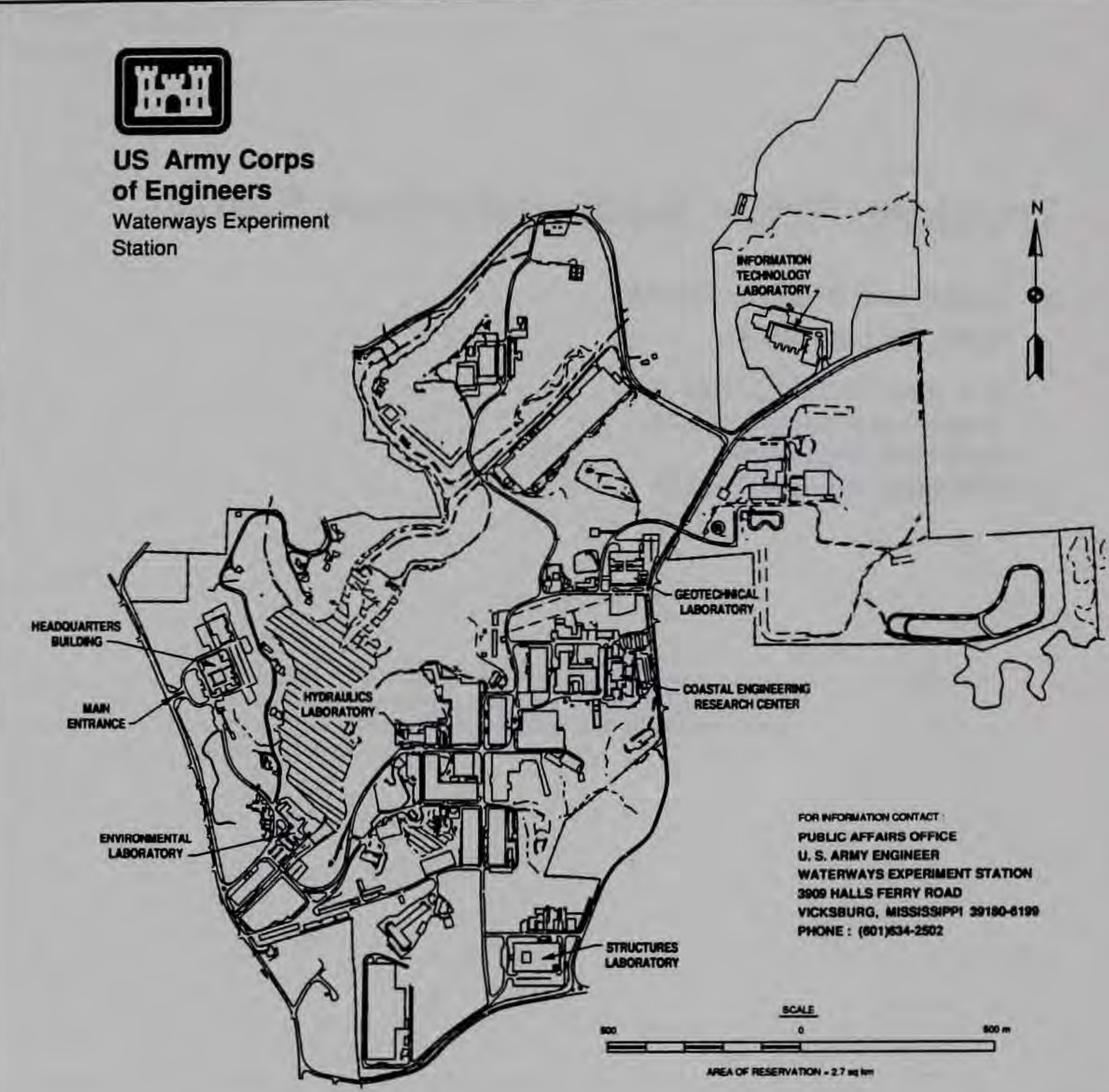

Waterways Experiment Station Cataloging-in-Publication Data

Hall, Brad R.

Truckee River sedimentation study / by Brad R. Hall, William A. Thomas; prepared for U.S. Army Engineer District, Sacramento.

46 p. : ill. ; $28 \mathrm{~cm}$. - (Technical report ; HL-93-13)

includes bibliographical references.

1. Sediment transport - Truckee River (Calif, and Nev.) 2. Truckee River (Calif. and Nev.) - Channels. 3. Bed load - Truckee River (Calif. and Nev.) Measurement - Data processing. 4. Sedimentation and deposition - Truckee River (Calif. and Nev.) - Data processing. I. Thomas, William A., 1938- II. United States. Army. Corps of Engineers. Sacramento District. III. U.S. Army Engineer Waterways Experiment Station. IV. Title. V. Series: Technical report (U.S. Army Engineer Waterways Experiment Station) ; HL-93-13.

TA7 W34 no.HL-93-13 


\section{Contents}

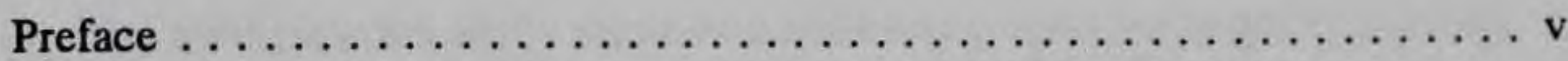

Conversion Factors, Non-SI to SI Units of Measurement $\ldots \ldots \ldots \ldots$ vi

1 -Introduction $\ldots \ldots \ldots \ldots \ldots \ldots \ldots \ldots \ldots \ldots \ldots \ldots \ldots \ldots \ldots \ldots$

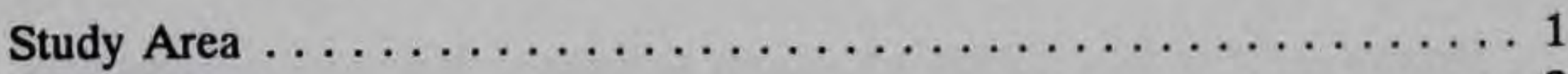

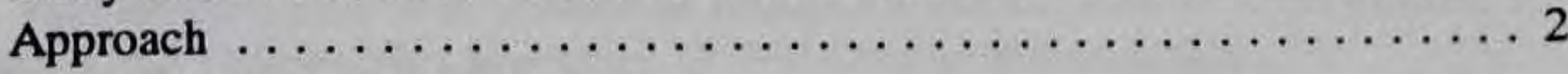

2-Inventory of Prototype Data $\ldots \ldots \ldots \ldots \ldots \ldots \ldots \ldots \ldots \ldots \ldots \ldots \ldots$

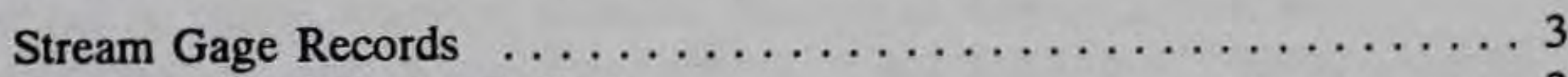

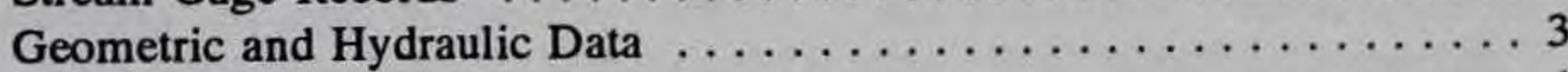

Bed Gradation Data $\ldots \ldots \ldots \ldots \ldots \ldots \ldots \ldots \ldots \ldots \ldots$

Soil Exploration $\ldots \ldots \ldots \ldots \ldots \ldots \ldots \ldots \ldots \ldots \ldots \ldots$

3-Analysis of Existing Channel $\ldots \ldots \ldots \ldots \ldots \ldots \ldots \ldots \ldots \ldots$

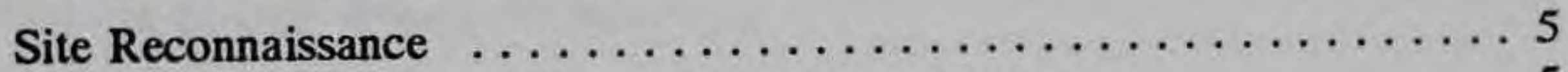

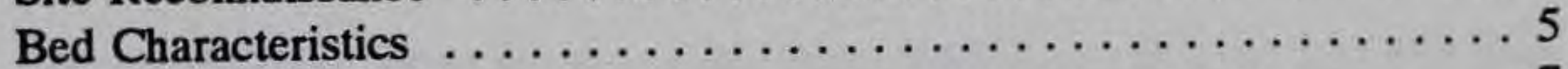

Suspended Sediment $\ldots \ldots \ldots \ldots \ldots \ldots \ldots \ldots \ldots \ldots \ldots \ldots$

4 Sedimentation Analysis $\ldots \ldots \ldots \ldots \ldots \ldots \ldots \ldots \ldots \ldots$

Assessment of Bed Load Transport and Deposition $\ldots \ldots \ldots \ldots \ldots$.

in the Study Area . . . . . . . . . . . . . . . . . . .

Stability of the Truckee River at Reno Stage-

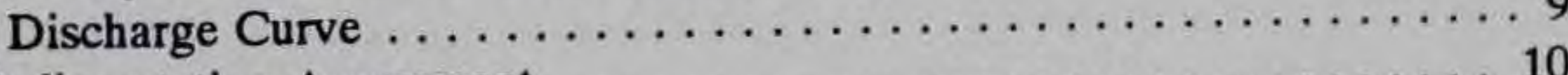

Sedimentation Assessment $\ldots \ldots \ldots \ldots \ldots \ldots \ldots \ldots \ldots \ldots \ldots \ldots$

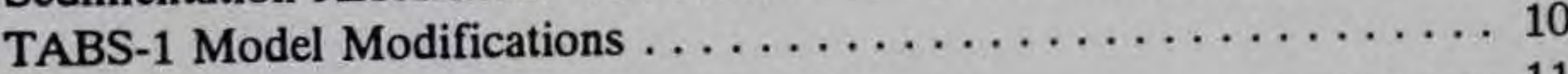

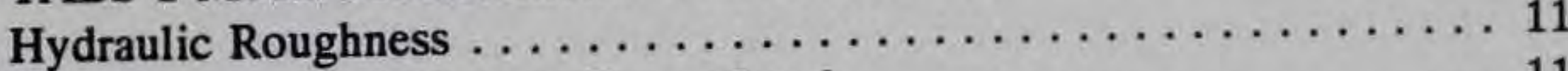

Determination of Inflow Sediment Load $\ldots \ldots \ldots \ldots \ldots \ldots \ldots \ldots$

Estimate of Equilibrium Bed Load Transport of

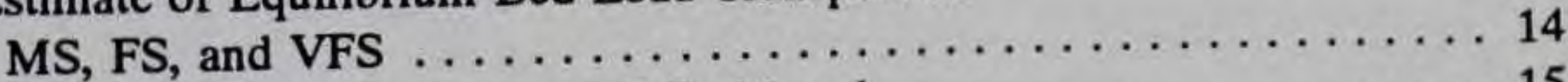

Estimate of the Average Annual Bed Load . . . . . . . . . . . 15

Estimate of the 100-year Flood Sediment Transport . . . . . . . 17

5-Summary, Conclusions, and Recommendations ........... 19

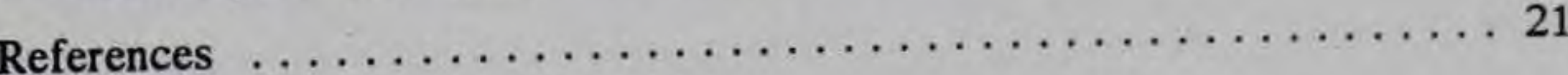


Tables 1-5

Figures 1-7

Plates 1-10

SF 298 


\section{Preface}

The sedimentation study reported herein was conducted at the U.S. Army Engineer Waterways Experiment Station (WES) at the request of the U.S. Army Engineer District, Sacramento (SPK), under DA 2544 No. CESPK-EDD-89-47, dated 20 July 1989.

This investigation was conducted during the period July 1989 to January 1990 in the Hydraulics Laboratory of WES, under the direction of Messrs. Frank A. Herrmann, Jr., Director of the Hydraulics Laboratory; Richard A. Sager, Assistant Director; Marden B. Boyd, Chief of the Waterways Division, Hydraulics Laboratory; and Michael J. Trawle, Chief of the Math Modeling Branch, Waterways Division. The Project Engineer for this study was Mr. Brad R. Hall, Math Modeling Branch, who also prepared this report with Mr. William A. Thomas, Waterways Division, who provided technical guidance. Ms. Lisa G. Porter, Math Modeling Branch, provided technician support throughout this study.

Mr. Ed Sing served as the Hydraulic Project Engineer in SPK, and Mr. Dan Pridal served as the Hydraulic Design Engineer in SPK. Both individuals provided valuable contributions and guidance during the course of this study.

At the time of publication of this report, Director of WES was Dr. Robert W. Whalin. Commander was COL Bruce K. Howard, EN. 


\section{Conversion Factors, Non-SI to SI Units of Measurement}

Non-SI units of measurement used in this report can be converted to SI units as follows:

\begin{tabular}{||l|l|l||}
\hline Multiply & By & To Obtain \\
\hline cubic feet & 0.02831685 & cubic meters \\
\hline feet & 0.3048 & meters \\
\hline miles (U.S. statute) & 1.609347 & kilometers \\
\hline square miles & 2.589998 & square kilometers \\
\hline tons (2,000 pounds, mass) & 907.1847 & kilograms \\
\hline
\end{tabular}




\section{Introduction}

\section{Study Area}

The U.S. Army Engineer Sacramento District (CESPK) is formulating a local flood protection project along the Truckee River at Reno, Nevada. The District is completing a Sediment Engineering Investigation (SEI) in conjunction with the project design to assess existing and project condition sedimentation processes of the Truckee River. This report is part of the SEI and provides an assessment of the existing sedimentation conditions of the study reach. A sediment budget and associated channel changes for both average annual and design flood conditions are developed in this report.

The Truckee River study reach is located near Reno, Nevada and extends from the Vista gage at approximately River Mile (RM) 43.9 to just upstream of the Booth Street bridge at RM 53.0. A map of the study area is shown on Figure 1. A number of inflow points occur along the study reach including urban inflows, irrigation diversion wasteways, and tributary drainages. Two major tributaries provide additional discharge; Steamboat Creek at RM 45.5 and the North Fork Truckee drain at RM 44.8. The Truckee River watershed upstream of the study reach includes the Lake Tahoe watershed and portions of the eastern slope of the Sierra Nevada mountains in California and Nevada. The Truckee River watershed area at the upstream end of the study reach is approximately 1,067 square miles. ${ }^{1}$ The majority of the Truckee River runoff originates in the Sierra Nevada mountains and flows through the study reach. Downstream of the study reach, the Truckee River flows east-northeast until it empties into Pyramid Lake, 43 miles downstream of the Vista gage. Pyramid Lake is a terminal lake for the river basin which has no outlet to the ocean.

The Truckee River is a perennial stream characterized by pool and riffle channel morphology. Several bridge crossings and water diversion structures are found in the study reach. Man made channel modifications, especially within the upper 3 miles of the study reach, have limited the amount of channel migration. Bed material size decreases through the reach, and the channel bed is armored at base flow discharge. The flood plain and back water storage

1 A table of factors for converting non-SI units of measurement to SI units is found on page $v$. 
areas have been encroached upon by areas of urban construction and earth fill in recent years.

\section{Approach}

The U.S. Army Engineer Waterways Experiment Station (WES) computer program "Sedimentation in Stream Networks", Version 2.00, 9 October 1989 (TABS-1) was used to investigate the channel conditions and quantify channel response to discharge variations. A detailed description of the assumptions, limitations, and data requirements for the code is provided in Appendix A of Copeland and Thomas (1989). The study reach of the Truckee River has insufficient sampled sediment transport rates, suspended sediment concentrations, and channel surveys to document river channel migration and profile changes to permit the normal numerical model adjustment and circumstantiation. The study combined a theoretical treatment of the sediment transport processes with observed channel morphology and fluvial hydraulics expertise to quantify channel bed dynamics associated with gravel and boulder fluvial processes. The primary purpose of the sedimentation analysis was to investigate the channel sedimentation processes for existing river conditions. The effects of channel overflow and associated suspended sediment deposition in the floodplain were not considered in the analysis.

The approach taken for this investigation was to simulate the existing channel sedimentation conditions, and compare the computed results with observed prototype conditions. Instead of quantifying instantaneous sediment transport rates, the analysis allowed evaluation of channel response to long term hydrologic sequences. Observation and analysis of the present channel conditions in conjunction with the computed model results were used to develop the conclusions and recommendations presented at the end of this report. The base test contains the existing channel geometry as surveyed in 1975 , hydraulic contraction and expansion coefficients taken from the HEC-2 (Hydrologic Engineering Center, 1982) water surface profile data file developed by CESPK for the project reach, an estimate of the inflowing sediment discharge and inflowing sediment grain size distribution, and bed sediment gradation developed from bed material samples and Wolman counts taken in 1989. The existing condition 100-year flood hydrograph was developed from HEC-1 (Hydrologic Engineering Center, 1981) hydrologic routings provided by CESPK. Average annual flow exceedence statistics were developed by Water Engineering and Technology, Inc. (1989). 


\section{Inventory of Prototype Data}

\section{Stream Gage Records}

There are three United States Geological Survey (USGS) stream gages on the Truckee River study reach (US West Optical, 1988). Stream gage locations are shown on Figure 1. The gages and the period of record for streamflow data at each gage are listed in the following tabulation.

\begin{tabular}{||l|l|l||}
\hline \multicolumn{3}{|c||}{ USGS Stream gages in the study reach. } \\
\hline \hline Gage & $\begin{array}{l}\text { Drainage Area, } \\
\text { square miles }\end{array}$ & Period of Record \\
\hline $\begin{array}{l}\text { Truckee River at Reno, Nevada } \\
\text { USGS Gage No. 10348000 }\end{array}$ & 1067 & $1907-1988$ \\
\hline $\begin{array}{l}\text { Truckee River near Sparks, Nevada } \\
\text { USGS Gage No. 10348200 }\end{array}$ & 1070 & $1977-1988$ \\
\hline $\begin{array}{l}\text { Truckee River at Vista, Nevada } \\
\text { USGS Gage No. 10350000 }\end{array}$ & 1431 & $1900-1988$ \\
\hline
\end{tabular}

\section{Geometric and Hydraulic Data}

Geometry was developed from channel and overbank surveys from a 1975 data base provided by CESPK. Cross-sectional geometry was provided in HEC- 2 X1 and GR card format. Bridge data were developed from 1989 field surveys of bridge geometry including low and high chord profiles, and bridge pier location and orientation. Non-dimensional Manning's n values and channel expansion and contraction coefficients were provided by CESPK in a HEC2 data file for the study reach. Manning's n values varied from 0.028 to 0.038 for the river channel and 0.04 to 0.08 for overbank areas. Expansion coefficients range from 0.3 for natural river reaches to 0.5 for bridge crossings. Contraction coefficients range from 0.1 for natural river reaches to 0.3 for bridge crossings. 


\section{Bed Gradation Data}

In June 1989, 20 sediment samples were collected from the channel bed, bars and bank at 15 locations spaced along the 9 mile study reach. Samples were taken near the water's edge, from the channel bed, and from locations on point and mid-channel bars. These samples were processed by CESPK and the results were provided to WES for this sedimentation assessment. Due to close proximity of some of the sample sites, all locations are not individually represented on the channel thalweg profile. The locations of the bed material samples collected are shown on Figures 2 and 3 . Figures 2 and 3 also indicate the channel thalweg profile as determined from 1975 cross-sections, and the computed water surface profile for a discharge of $25,000 \mathrm{cfs}$.

Wolman count (Wolman, 1954) bed surface material gradations were collected as part of the geomorphological study of the Truckee River (Water Engineering and Technology, Inc., 1989). This method of analysis provides an estimate of the surficial coverage of the channel bed by coarse grain sediments (i.e. cobbles) which are generally omitted in bulk material samples. Profiles of the percent finer for each sediment size class sampled in the grab samples and the Wolman counts used for the numerical model application are given on Plates 1 and 2, respectively. The grain size delineation is described in further detail in Part III of this report.

\section{Soil Exploration}

Borings were taken along the channel bank and bridge sites in 1972 (Sacramento District, 1981). In addition, boring logs are available at several of the bridge crossings in the study reach. The borings indicate a complex mixture of boulders, cobbles, and gravels with interstitial sands and silts. The channel bed materials are similar in gradation to the coarse fraction of the soils adjacent to the river channel. 


\section{Analysis of Existing Channel}

\section{Site Reconnaissance}

Several site reconnaissance field trips were taken to the study area during the duration of this study. The date(s) of the reconnaissance, and the organizations represented on the trip are listed in the following tabulation. Field estimates of the Truckee River flow rate are also provided.

Field Reconnaissance Trips to the Study Area

a. 9 - 11 May 1989 (U.S. Army Engineer Committee on Channel Stabilization, 50th meeting) $(1000 \mathrm{cfs})$

b. 19 - 22 June 1989 (WES, U.S. Army Engineer Hydrologic Engineering Center (HEC), and CESPK). (400 cfs)

c. 24 - 27 July 1989 (WES). ( $\leq 300 \mathrm{cfs})$

d. 28 - 31 August 1989 (WES, HEC, CESPK, and Water Engineering and Technology, Inc.) $(\leq 300 \mathrm{cfs})$

Active bed load transport was not observed on any of the field trips. Water clarity was very high on each field trip as well, indicating very low suspended sediment concentration in the river.

\section{Bed Characteristics}

The type and distribution of bed materials in the Truckee River in the project area are a function of local stream shear stress and sediment supply. The former is a product of the energy gradient and the hydraulic radius of the channel (considering the specific weight of water in the channel as constant). Local sediment supply is dictated by the nature of the material encountered in the bed as the river degrades, the amount of sediment introduced by local inflow, and channel modifications. In the project reach both stream shear 
stress and local sediment supply are highly variable; however, the latter appears to have the most profound influence on the nature of the bed material.

Field observations of the project area in 1989 indicate that the Truckee River can be generally considered as three separate and distinctive reaches in terms of channel and bed characteristics. These reaches are identified as (a) the reach from the upstream limit of the study area to the Highway 395 bridge, (b) from Highway 395 bridge to just downstream of the McCarran Boulevard Bridge at RM 47.5, and (c) the reach from RM 47.5 to the downstream limit of the study area at the Vista Gage. Each reach is characterized by distinctive bed material types, size distributions, and bed forms.

The reach upstream of Highway 395 bridge may be described as an armored riffle/pool series. The Truckee River appears to be incised into the coarse sediments of the Tahoe and Donner Lake outwash deposits. The large boulders of the Tahoe and Donner Lake formations are apparently armoring the bed causing an irregular series of riffles and pools whose distribution is controlled by the intersection of the Truckee River with boulder beds in the underlying deposits. The channel is relatively straight with local high energy gradients in the boulder riffles. In the "downtown" area (RM 51.7 to RM 52.2), bridge abutments and piers have caused local scour and deposition. There is a noticeable absence of boulders in the river channel in the downtown area. Excavations adjacent to the channel indicate that boulders are present in this area, thus it appears that boulders were removed from the river channel since the existing channel improvements were constructed. The principal geomorphic activity of the Truckee River in this reach appears to be gradual bed degradation and winnowing of the finer (sand and gravel) materials encountered in the outwash deposits. As the Truckee continues to degrade slowly in this reach, the bed will maintain an armor of cobbles and boulders derived from the outwash deposits.

From the Highway 395 bridge to RM 47.5, the Truckee exhibits a slightly meandering planform with a marked decrease in the size of the bed material. Several types of bars occur including point, alternate, and mid-channel bars. This reach is apparently a sediment storage reach where the coarse bed load that passes through the upstream reach is gradually deposited in several river bars. The distribution of the alternate and point bars suggest that the coarser point bars are formed and maintained by higher discharges and the alternate bars by more frequent lower stage flows (Water Engineering and Technology, Inc. 1989). This reach is generally experiencing slow lateral migration through point bar growth and bank migration.

Below RM 47.5 the Truckee River changes to a gently meandering channel which is incising into fine-grained cohesive alluvium. The fine grained alluvium consists of slack-water deposits of silty clays which were possibly deposited during an earlier blockage of the Truckee River at Vista. The bed consists of irregularly distributed scour pools incised into the cohesive slackwater deposits. Gravel material appears infrequently on the bed, which generally consists of sand or a clean erosional flute in the underlying silty clays. 
The number of bars decrease considerably in this lower reach as the channel generally decreases in sinuosity. Steep channel banks may be unstable locally as indicated by several large rotational slides.

\section{Suspended Sediment}

The USGS WATSTORE data base was reviewed for sampled sediment discharge and stage - discharge rating curve shifts. Miscellaneous water quality parameters have been sampled at the Truckee River at Farad (USGS Gage No. 10346000) and the Truckee River at Nixon (USGS Gage No. 10351700) gages. Both of these gages are located several miles downstream of the project reach. However, there are insufficient data to develop a suspended sediment - discharge rating curve for the Farad Gage, and the Nixon gage is downstream of the Truckee Meadows area and is subject to sediment inflow from the canyon through which the river flows between Vista and the Nixon gage. Discussions with USGS personnel in the Carson City, Nevada Regional Office indicate that measurements of sediment transport rates in the Truckee River in the Truckee Meadows and Reno, Nevada area have only been done for a very few instances (Rita Carmen and Dick Lacamera, USGS Carson City, Nevada Office, personal communication, October 1989). Provisional records from the USGS provided the concentrations listed in Table 1 . The maximum concentration sampled for the Truckee River at Vista gage (USGS gage no. 10350000) was 950 milligrams per liter at a discharge of approximately 7500 cfs. Review of USGS records (USGS, 1986), University of Nevada at Reno publications, and computerized bibliographic searches at the WES technical library indicated that no measurements of bed load transport have been documented for the project reach of the Truckee River.

Suspended sediment concentration and discharge have been sampled at a few locations in the Truckee River at Reno and points downstream as part of water quality and water supply studies (James Brock, water quality consultant to the City of Reno, personal communication, October 1989). The suspended sediment concentration data sampled at McCarran Boulevard (RM 47.7) are tabulated in Table 2.

The gradations of the suspended sediment samples listed in Tables 1 and 2 were not measured, so estimating the source of the suspended load (i.e. bed material load or wash load) is impossible. A rating curve for suspended load versus flow rate can be developed from the data in Table 2 . A power regression, which appears as a straight line when plotted on log-log graph, was used to estimate the suspended sediment concentration rating curve. The data and the regression line are plotted on Figure 4 . The power regression equation is:

$$
C_{s}=8.97\left(10^{-4}\right) Q^{1.47}
$$


where

$\mathrm{C}_{\mathrm{s}}=$ the suspended sediment concentration in mg per liter

$\mathbf{Q}=$ the Truckee River flow rate in cfs

The regression coefficient for this equation (i.e. $\vec{r}^{2}$ ) is 0.69 .

This suspended sediment relationship can be used to determine the annual suspended sediment load at this location of the Truckee River. The flowduration curve developed for the Truckee River at Reno gage (Water Engineering and Technology, Inc. 1989, Figure 4.4) can be combined with the suspended sediment load curve to estimate the average annual suspended load of the Truckee River at McCarran Boulevard. This analysis assumes that the flow-duration curve for the Truckee River at Reno gage is representative of the flow-duration characteristics of the Truckee River at McCarran Boulevard. The suspended sediment concentration curve - flow rate regression must be converted to a suspended sediment discharge - flow rate rating curve using the relationship:

$$
Q_{s}=(0.0027)\left(C_{s}\right)(Q)
$$

where

$$
Q_{S}=\text { the suspended sediment discharge in tons per day. }
$$

Combining the flow-duration curve with the suspended sediment discharge relationship yields an average suspended sediment load at McCarran Boulevard of 700 tons/day or approximately 250,000 tons/year. This value of average annual sediment load is approximately twice the value of 122,700 tons per year at the Vista Gage developed in MacArthur (1982). The difference in values is probably due to the methods used to determine sediment load. MacArthur's value was determined from estimates of watershed erosion, while the estimate provided in this report was developed from a limited amount of sampled suspended sediment discharge data. 


\section{Sedimentation Analysis}

\section{Assessment of Bed Load Transport and Deposition in the Study Area}

The geomorphic study of the Truckee River indicates that sediment storage is progressing between River Miles 50.6 and 46.7 (Water Engineering and Technology, Inc., 1989, paragraphs 7.4, 7.5). The sediments that are depositing in this reach of the river can be characterized as cobble-gravel mixture, with minor amounts of interstitial sand. The mode of transport of these large sized sediments is most likely bed load transport. To assess the rate of bed load deposition, an analysis of measured hydraulic changes and a numerical assessment of the bed load transport rate through the study area was performed.

\section{Stability of the Truckee River at Reno Stage- Discharge Curve}

The stage-discharge rating curve developed by the USGS for the Truckee River at Reno, Nevada (gage No. 10348000) was reviewed for any significant changes in the rating. The gage is located near the Highway 395 bridge at approximately RM 50.6. The measurements indicate a very stable stagedischarge relationship through 1977. After 1977, a slight increase in stage over time for low discharges can be detected. The rating curves used through 30 September 1977, 3 February 1982, and 17 February 1986 are plotted for comparison on Plate 3 . The rating curves indicate that for discharges less than $1000 \mathrm{cfs}$, the stage has increased approximately 0.5 foot at the gage. The increase in stage for a given discharge rapidly diminishes for discharges greater than $1000 \mathrm{cfs}$. Possible reasons for the change in the stage-discharge relationship are (a) a gradual channel aggradation at the gage location, and/or (b) changes in the relative roughness characteristics of the channel at discharges less than $1000 \mathrm{cfs}$, and/or (c) changes in the channel morphology that has altered the stage-discharge relationship. The specific reason for the change in stage-discharge relationship can not be determined from the rating curve records. However, if the change can be attributed to channel aggradation, the aggradational trend indicates that channel fill is occurring at a sluggish rate 
and that the aggradational trend does not significantly effect the stage discharge relationship for discharges greater than $10,000 \mathrm{cfs}$.

\section{Sedimentation Assessment}

The numerical simulation model "Sedimentation in Stream Networks", version $2.00,9$ October 1989 (TABS-1) was used to calculate the unsampled bed load transport inflow to the study area, the transport rate by grain size throughout the study reach, and the depositional quantities and distribution for selected design events. The procedures that were required for developing the hydraulic conditions, sediment properties, and sediment transport rates are described in the following paragraphs.

\section{TABS-1 Model Modifications}

Modifications to the TABS- 1 source code were required to better simulate the hydraulic and sediment conditions identified in the prototype. The first modification included modifying the manner in which geometric data are entered at bridge cross sections. Additional geometric data are entered on the cross-sectional geometry records (GR cards) to specify bridge piers, and ineffective flow area between the high and low chords of the bridge. The geometric calculations account for the additional wetted perimeter and reduced flow area. The calculations are similar to the "normal bridge" method in the HEC-2 Water Surface Profile model. The second modification dealt with increasing the maximum transportable grain size. The maximum transportable grain size in previous versions of TABS-1 was $64 \mathrm{~mm}$. A significant amount of the bed material in the study area is of a nominal diameter much greater than $64 \mathrm{~mm}$. The version of TABS-1 used for this study accounts for the transport of up to fifteen grain sizes by specifying the minimum grain size and the multiplier between grain size classifications. The grain size classification used for this study follows the American Geophysical Union classification proposed by Lane (1947) and given in the following tabulation.

\begin{tabular}{||l|l|l||}
\hline \multicolumn{3}{|c|}{ Grain sizz classification used In the Truckee River TABS-1 Model } \\
\hline Sediment Material & Classification & Grain Dlameter (mm) \\
\hline 1. Very Fine Sand & VFS & $0.0625-0.125$ \\
\hline 2. Fine Sand & FS & $0.125 \cdot 0.25$ \\
\hline 3. Medium Sand & MS & $0.25 \cdot 0.5$ \\
\hline 4. Coarse Sand & CS & $0.5-1.0$ \\
\hline 5. Very Coarse Sand & VCS & $1.0 \cdot 2.0$ \\
\hline 6. Very Fine Gravel & VFG & $2.0-4.0$ \\
\hline 7. Fine Gravel & FG & $4.0 \cdot 8.0$ \\
\hline
\end{tabular}




\begin{tabular}{||l|l|r||}
\hline 8. Medium Gravel & MG & $8.0 \cdot 16.0$ \\
\hline 9. Coarse Gravel & CG & $16.0 \cdot 32.0$ \\
\hline 10. Vory Coarse Gravel & VCG & $32.0 \cdot 64.0$ \\
\hline 11. Small Cobble & SC & $64.0 \cdot 128.0$ \\
\hline 12. Large Cobble & LC & $128.0 \cdot 256.0$ \\
\hline 13. Small Boulders & SB & $256.0 \cdot 512.0$ \\
\hline
\end{tabular}

\section{Hydraulic Roughness}

Estimates of the sediment transport potential are dependent upon the proper designation of the hydraulic roughness. The roughness coefficients used for the channel portion of the hydraulic calculations were estimated with the analytic roughness predictors contained in the "Hydraulic Design Package for Flood Control Channels (SAM)", version 2.3, dated 25 October 1989. The routines in the SAM code compute a Manning's n value based on bed material grain size distribution, and the relative roughness of the bed material to the channel hydraulic conditions. The Manning's $\mathrm{n}$ is calculated using the roughness predictor developed by either Brownlie (1983) or Limerinos (1970). The Limerinos relationship is better suited to roughness prediction for coarse grained (i.e. gravel and cobble) channels with no significant bed forms. The results of this analysis indicate that a Manning's n of 0.029 should be used for that portion of the river from Vista Gage (RM 43.9) to the Steamboat Creek confluence (RM 45.2), a value between 0.03 and 0.035 from Steamboat Creek to the urbanized Truckee River channel between Lake Street Bridge (RM 51.9) and Arlington Street Bridge (RM 52.3). Upstream of Arlington Street Bridge, the channel roughness should again return to 0.035 . The values of the channel Manning's $\mathrm{n}$ used in the HEC-2 input file provided by CESPK did not vary significantly from the Manning's n value determined with the Limerinos roughness predictor, so the roughness values used in the HEC-2 file were not changed for the sediment assessment.

\section{Determination of Inflow Sediment Load}

Bed load measurements on the Truckee River at the upstream end of the study reach were not available. The sediment inflow load to the study area was determined by calculating the equilibrium sediment transport rate for a range of flow rates for a reach of the Truckee River within the study area that has similar hydraulic characteristics to the river channel immediately upstream of the study area. This reach of river is termed the "equilibrium reach" and the portion of the Truckee River from approximately RM 50.5 to 51.5 can be characterized as exhibiting similar characteristics in channel planform, bed material, and channel bank characteristics as that portion of the Truckee River immediately upstream of the study area. The location of the equilibrium reach with respect to the study area is shown on Figure 5. The geomorphic analysis 
of the Truckee River indicates that the equilibrium reach and that portion of the Truckee River immediately upstream of the project are very similar in geomorphological characteristics (Water Engineering and Technology, Inc. 1989 , paragraphs $7.1,7.3$ ). The equilibrium reach is relatively unaffected by man made modifications such as channel bank stabilization structures and hydraulic modifications induced by bridge crossings.

Several sediment transport functions may be used in the TABS-1 simulation model. The transport function is chosen by specifying the value of the variable MTC on the 14 record of the TABS-1 input file that corresponds to the selected transport function (Hydrologic Engineering Center, 1989). For this application, the equations tested for determining the unknown bed load quantity are listed in the following tabulation.

Sediment transport equations tested for determining the bed load transport rate in the equilibrium reach. Variable MTC specified on 14 record of TABS-1 input file provided in parentheses.

a. Meyer-Peter and Muller equation $(\mathrm{MTC}=10)$

b. Combination Meyer-Peter, Muller and Tofalletti equations $(M T C=12)$

c. Madden modification of the Laursen equation $(M T C=13)$

d. Copeland modification of the Laursen equation (MTC $=14$ )

Determining the equilibrium bed load quantity requires an iterative application of the TABS-1 algorithm to the equilibrium reach until the estimated inflowing load for all size classes to the equilibrium reach is nearly equal to the transport capacity (by size class) at each cross sections in the reach after bed elevation changes have stabilized. The bed material gradation for the equilibrium reach must also be known. For this application, the bed material gradation was estimated from bed material samples obtained at RM 52.0 and a Wolman count at RM 50.5. Integration of these two bed material samples yields the bed material characteristics given in the following tabulation.

\begin{tabular}{||l|l||}
\hline \multicolumn{2}{|c|}{ Bed material gradation for the equilibrium reach } \\
\hline \hline Grain Size, $\mathrm{mm}$ & Percent Finer by Weight \\
\hline \hline 512.0 & 100 \\
\hline 64.0 & 35 \\
\hline 0.5 & 0 \\
\hline
\end{tabular}

TABS-1 was run at discharges of 1000,10000 , and $30000 \mathrm{cfs}$ at 0.1 day time steps for a period of 30 days to determine the equilibrium bed load for each of the sediment transport relationships given in paragraph 28 . The bed load transport rates, and associated bed profile changes, did not stabilize during 
the equilibrium load simulations, except for the Meyer-Peter and Muller equation. Excessive scour should not be computed in equilibrium reach calculations since excessive scour indicates that the coarse bed materials are being removed from the bed and the channel is not armoring. The field reconnaissance and the Wolman count bed material gradations indicate that the bed is well armored by cobble size sediments. The bed gradation at the end of the equilibrium reach calculations should be similar to the bed material gradation at the beginning of the simulation. If this condition is met, then the bed material gradation is in equilibrium with the computed transport rate. Since the Meyer-Peter and Muller bed load equation was the only equation which provided stable bed elevation changes for the equilibrium calculations, this relationship was chosen for simulating bed load transport and deposition in the study area. The calculated sediment bed load in the equilibrium reach for discharges of 1000,10000 , and $30000 \mathrm{cfs}$ is shown on Figure 6.

Discussion with CESPK and Water Engineering and Technology, Inc. personnel on preliminary sedimentation assessment results focused on the appropriate critical shear stress value to quantify bed load transport. Research on critical shear stress values for gravel transport indicates that there is a wide variability in the recommended method and appropriate value of critical shear stress. A practical application of the Meyer-Peter and Muller bed load transport equation is given in Carson and Griffiths (1989). They determined that raising the dimensionless critical shear stress in the Meyer-Peter and Muller bed load transport equation from 0.047 to 0.059 gave the best agreement for observed gravel transport on a braided gravel bed river of channel slope 0.0048. Wiberg and Smith (1987) developed an analytical method of computing critical shear stress for coarse, mixed grain size bed sediments. Their results indicate that the dimensionless critical shear stress for sediments with the characteristics of Truckee River riffles (Water Engineering and Technology, Inc. 1989, Figure 3.3) would be in the range of 0.03 to 0.06 . Boulder transport due to a dambreak flood surge on the Rubicon River in California was analyzed by Scott and Gravlee (1968). They determined the maximum tractive force at several locations by measuring the diameter of the maximum size boulder that was moved by the flood surge, the water surface slope, and the depth of flow. The critical shear stress measurements for boulder transport determined by Scott and Gravlee are tabulated at the end of this paragraph.

Due to the variability of analytically computed and field measurements of critical shear stress values on gravel and boulder bed rivers, and the cited references which indicate that critical shear stress should be increased for determining bed load transport of gravel, no reason for decreasing the recommended value of the dimensionless critical shear stress of 0.047 in the MeyerPeter and Muller bed load transport equation for computing sediment transport could be justified for this study. The Equilibrium Reach bed load transport rating curve is given on Plate 4 . 


\begin{tabular}{||l|l|l||}
\hline \multicolumn{3}{|c||}{ Measured Critical Shear Stress, Rubicon River, California } \\
\hline $\begin{array}{l}\text { Mean Particle } \\
\text { Diameter, foet }\end{array}$ & $\begin{array}{l}\text { Critical Tractive } \\
\text { Force, pounds/sq. foot }\end{array}$ & $\begin{array}{l}\text { Nondimensional } \\
\text { Shear Stress }\end{array}$ \\
\hline 2.05 & 5.5 & 0.026 \\
\hline 1.50 & 6.8 & 0.044 \\
\hline 1.57 & 7.3 & 0.045 \\
\hline 2.95 & 11.9 & 0.040 \\
\hline 1.63 & 13.7 & 0.082 \\
\hline 6.00 & 64.5 & 0.105 \\
\hline 4.74 & 71.6 & 0.148 \\
\hline 7.80 & 116. & 0.146 \\
\hline 10.8 & 101. & 0.092 \\
\hline
\end{tabular}

\section{Estimate of Equilibrium Bed Load Transport of MS, FS, and VFS}

Negligible amounts of sediments smaller than coarse sand $(0.5 \mathrm{~mm})$ are present in the bed material samples upstream of the equilibrium reach (RM 50.5 to 51.5). Thus bed material transport of sediments this size class and smaller could not be determined from the equilibrium reach calculations described in the previous paragraphs. To estimate the quantity of sediment smaller than coarse sand that is seen in the river bar samples downstream of the equilibrium reach, a second equilibrium reach was selected between Steamboat Creek (RM 45.3) and the Vista Gage (RM 43.9) (Figure 5). The transport function used was the Meyer-Peter and Muller relationship. This transport function was used to be consistent with the mode (i.e. bed load) of sediment transport being simulated through the upstream end of the study reach. Additional fine sediment may be transported through the study area as suspended load, but sampled suspended load data indicate that there is sufficient energy in the flow to pass the suspended load through the study reach as washload. A comparison of the suspended sediment data sampled at the Sparks gage (RM 50.4), the Vista Gage (RM 43.9), and McCarran Boulevard (RM 47.7) is shown on Figure 7. A comparison is provided for the best fit power regression between the McCarran Boulevard data and the Sparks gage and Vista gage data points. The regression coefficients for the Sparks and Vista gage data points are nearly equivalent to the regression coefficients from the McCarran Boulevard data alone. This indicates that the suspended load is actually wash load and thus does not need to be considered in the analysis of channel bed profile changes.

Bed material samples from channel bars at RM 45.6 in this reach indicate that the maximum grain size is approximately $64 \mathrm{~mm}$ and that approximately ten percent of the material is finer than medium sand. The equilibrium 
transport for these size classes would pass through the upper end of the study area as wash load. Thus, the sediment load for medium sand, fine sand, and very fine sand determined in this reach can be added to the total load calculated for the sediment inflow to the study area. The result of this procedure is to develop an equilibrium total sediment bed load curve at the upstream end of the study reach. This sediment bed load is broken down by grain size in Table 3.

The sediment transport rates listed in Table 3 do not include the suspended sediment transport load, which would consist of sediment finer than medium sand. As shown in Tables 1 and 2, sampled suspended sediment concentrations are very low. Preliminary calculations using total load sediment transport equations (e.g. Tofalletti, Laursen) indicate that the sediment transport capacity of medium sand, fine sand, and very fine sand is higher than the sampled suspended load for the downstream portion of the study area. Thus the transport rate of very fine sand, fine sand, and medium sand in Table 3 represent the amount of these size class sediments being transported as washload at the upstream limit of the study area.

\section{Estimate of the Average Annual Bed Load}

A hydrograph that approximates the average annual hydrograph for the Truckee River at Reno was simulated. The flow-exceedence relationship was developed from the geomorphic analysis of the Truckee River (Water Engineering and Technology, Inc., 1989, Figure 4.5). The average annual hydrograph characteristics are tabulated below.

\begin{tabular}{||l|l||}
\hline \multicolumn{2}{|c|}{ Average Annual Hydrograph Characteristics } \\
\hline Flow Rate, cfs & Exceedence Frequency \\
\hline 5480. & 0.10 \\
\hline 2450. & 0.20 \\
\hline 1410. & 0.33 \\
\hline 707. & 0.46 \\
\hline 375. & 1.00 \\
\hline
\end{tabular}

Prototype observations (paragraphs 11 through 21) and TABS-1 simulations indicate negligible sediment transport at the $375 \mathrm{cfs}$ discharge. To minimize computer simulation time, the $375 \mathrm{cfs}$ discharge was not run for the production simulations. The average annual hydrograph was simulated for a nine year period to compare computed with measured shifts in the rating curve for the Truckee River at Reno gage (Plate 3). Computed bed elevation changes at the end of the nine year simulation period are plotted on Plate 5. The results indicate that extensive deposition occurs at the downstream portion of the study area. The computed rating curve shift for the 9 year simulation period 
for the Truckee River at Reno Gage also indicates aggradation at the gage location in excess of the measured gage shift (paragraph 23, Plate 3).

The simulation results using the equilibrium reach bed load (Figure 5) indicate that the computed bed load transport into the study area is excessive. The total bed load transport rating curve was adjusted until a better match was obtained between computed and observed sediment deposition quantities and zones, as measured by bed elevation changes through the study area after the nine year simulation period, and reasonable changes in both magnitude and trend in the observed rating curve shift at the Truckee River at Reno gage. The total bed load sediment inflow rating curve was adjusted downward to 33 percent of the bed load transport rate computed from the equilibrium reach. The adjusted bed load inflow rate used for existing condition simulations is given in Table 4.

The computed rating curve shift for the Truckee River at Reno gage using the adjusted bed load inflow rating curve is given as follows.

\begin{tabular}{|c|c|c|}
\hline \multicolumn{3}{|c|}{$\begin{array}{l}\text { Comparison of Computed Shift with Observed Shitt in the Rating Curve for the Truckee } \\
\text { River at Reno Gage, Nine Years Simulation. }\end{array}$} \\
\hline Flow Rate, cfs & Computed Shitt, feet & Observed Shift, feet \\
\hline 707. & 1.4 & 0.5 \\
\hline 1410. & 0.8 & 0.3 \\
\hline 2450. & 0.1 & 0.2 \\
\hline 5480. & 0.0 & 0.1 \\
\hline
\end{tabular}

Computed bed elevation changes for the study reach after the nine year simulation period are plotted on Plate 6. Computed accumulated bed load through the study reach after 1 year and after nine years simulation time are plotted on Plate 7. The accumulated bed load indicates storage of bed material upstream of the three irrigation diversion drop structures between RM 49.1 and 50.1 . Storage of the bed load behind the drop structures in the first year of the simulation period results in scour downstream of the drop structures from RM 49 to approximately RM 48. This storage upstream of the drop structures and scour downstream of the drop structures is filled over the simulation period of nine years, and armoring of the bed downstream of the drop structures results in relatively uniform transport of bed load from the upstream limit of the study area at RM 53 downstream to approximately RM 48. Downstream of RM 48, a relatively uniform reduction in the total bed load transport rate from RM 48 to $R M 44$ is computed.

The nine year average annual flow simulation indicates that significant amounts of deposition occurs downstream of McCarran Avenue Bridge at RM 47.7. Extensive bar development is not apparent in the prototype at this location. Sediment storage in the prototype is primarily observed between 
Highway 395 and the McCarran Avenue bridge. Possible reasons for this discrepancy between the computed and observed conditions are errors in the computed hydraulic conditions downstream of RM 47.7 resulting in computed sediment transport being too low, or errors in the computed hydraulic conditions between Highway 395 and McCarran Avenue Bridge resulting in computed sediment transport capacity being too high in this reach.

The nine year sedimentation analysis of the study reach provides a means for estimating the average annual bed load transport at several locations. The TABS-1 results indicate sedimentation storage between RM 47.3 and RM 44.4. The average annual bed load at the upstream study limit, RM 47.3, RM 44.4, and the downstream study limit are given in Table 5. The computed average annual bed load inflow to the study reach is approximately 51,000 tons per year. Sampled suspended sediment concentration in the study reach indicated an average annual suspended sediment discharge of 250,000 tons per year. The computed bed load discharge is approximately 17 percent of the total sediment discharge. The computed average annual trap efficiency for bed load of the study reach is 71 percent.

\section{Estimate of the 100-year Flood Sediment Transport}

The 100-year recurrence interval flood simulation was completed to assess the quantity and location of sediment scour or deposition within the project reach for the design flood. The flood hydrograph was developed from HEC-1 flood hydrograph routing model output provided by CESPK. The flood hydrograph used is plotted on Plate 8 . To minimize the effects of initial bed material and bed profile gradations, the flood hydrograph was appended to the end of the nine year simulation of average annual hydrographs (paragraph 35 ). The differences in bed elevations and sediment scour or deposition between the end of the nine year spinup hydrograph and the 100-year flood hydrograph was used to quantify 100 -year flood sedimentation parameters. Computed bed elevation changes at the end of the 100-year flood hydrograph are plotted on Plate 9. The accumulated bed load passing each cross section in the study reach at the end of the 100 year flood is plotted on Plate 10. The 100-year flood simulation results indicate the following:

a. Passage of the inflowing sediment load through the downtown reach to approximately RM 51.8 .

b. Channel scour and associated increase in sediment load from RM 51.8 through RM 50.8. The scour is primarily due to channel adjustment and armoring to the high flow rate.

c. Transport of the increased load to RM 49. 
d. Gradual trapping and reduction of the sediment load from RM 49 to RM 47.

e. Transport of the reduced load out of the study reach. 


\section{Summary, Conclusions, and Recommendations}

Sediment transport theory was combined with evidence developed from field reconnaissance to quantify the bed load inflow rating curve for the Truckee River at Reno, Nevada. The technique used is called the equilibrium reach method, and develops the sediment load based on sediment transport theory, channel thalweg stability, and bed material gradation stability.

To improve the comparison between computed and observed sediment deposition quantities and zones, the bed load inflow rating curve was adjusted downward to 33 percent of the equilibrium reach sediment inflow. TABS-1 simulation using the adjusted sediment load inflow rating curve resulted in reasonable agreement between observed and computed rating curve shifts for the time period of 1977 and 1986 for the USGS Truckee River at Reno Gage.

The computed average annual bed load inflow to the study reach is approximately 17 percent of the total sediment inflow. The computed average annual bed load trap efficiency of the study reach is 71 percent.

Simulation of the 100-year flood sedimentation processes for existing river conditions indicates that localized channel adjustment in downtown Reno occurs throughout the flood hydrograph. Net channel bed scour or deposition after the 100 -year flood is less than 2 feet of bed change.

The Meyer-Peter and Muller bed load transport equation is a reasonable estimator of bed load transport for the study reach. Incorporation of cobble sized bed material in the sediment transport equations simulates the armoring and reduction of bed material availability for transport.

Direct determination of sedimentation changes due to channel modification cannot be based solely on the existing condition simulation documented in this report. Assessment of channel stability on instantaneous hydraulic conditions (shear stress, depth averaged velocity, and stream power) does not consider long term sediment transport conditions, and does not address the effects of sediment inflow to the study area on project channel stability. Channel changes result from the balance of sediment transport into a reach, the sediment transport capacity of the reach, and the sediment availability in the reach. 
The existing condition TABS-1 sedimentation analysis of the Truckee River completed for this study indicates that channel adjustment occurs throughout the design flood hydrograph. Due to sediment inflow to the project reach, continued channel adjustment for the project condition channel could be expected. Of interest to the project channel design is the channel stability, as measured by channel changes, for a range of hydrologic conditions. Simulation of the sediment transport through the project reach is required to address the sediment balance and subsequent project channel stability. In order to quantify the channel adjustment for project conditions, a sediment transport model for project conditions should be developed. The TABS-1 model developed to assess existing condition sediment transport through the project reach could be modified to simulate project conditions.

TABS-1 simulation using the adjusted sediment inflow rating curve computed excessive sediment deposition downstream of the prototype's observed sediment deposition zone. Additional adjustments are needed to reduce degradation between RM 53 and RM 51 and aggradation between RM 46 and RM 44. The study does allow, however, a reasonable estimate of annual sediment yield for flood control channel design. The bed-load inflow of 51,000 tons per year may be high, but the design value is bracketed between that and the calculated outflow of 15,000 tons per year. Advancements in sediment transport theory for coarse sediments are needed to reduce this range. 


\section{References}

Brownlie, W. R. (1983). "Flow Depth in Sand-Bed Channels." Journal of the Hydraulics Division, American Society of Civil Engineers, Vol. 109, No. HY7, pg. 959-990.

Carson, M. A. and Griffiths, G. A. (1989). "Gravel Transport in the Braided Waimakariri River: Mechanisms, Measurements and Predictions." Journal of Hydrology, Vol. 109, pg. 201-220.

Copeland, R. R. and Thomas, W. A. (1989). "Corte Madera Creek Sedimentation Study." U.S. Army Corps of Engineers, Waterways Experiment Station, Technical Report HL-89-6.

Hydrologic Engineering Center (1989). "HEC-6, Scour and Deposition in Rivers and Reservoirs Users Manual", Hydrologic Engineering Center, Davis, California (DRAFT Document)

Hydrologic Engineering Center (1982). "HEC-2, Water Surface Profiles Users Manual", U.S. Army Engineer Hydrologic Engineering Center, Davis, California.

Hydrologic Engineering Center (1981). "HEC-1, Flood Hydrograph Package Users Manual", U.S. Army Engineer Hydrologic Engineering Center, Davis, California

Lane, E. W. (1947). "Report of the Subcommittee on Sediment Terminology," Transactions, American Geophysical Union, Vol. 28, No. 6.

Limerinos, J. T. (1970). "Determination of the Manning Coefficient from Measured Bed Roughness in Natural Channels." U.S. Geological Survey Water Supply Paper 1989-B.

MacArthur, R. C. (1982). "Watershed Sedimentation Investigation for the Truckee River Basin, Verdi to Vista", Special Projects Memo No. 82-4, U.S. Army Corps of Engineers, Hydrologic Engineering Center.

Sacramento District. (1981) "Soils and Geology Office study. Truckee Meadows Investigation", U.S. Army Engineer District, Sacramento. 
Scott, K. M. and Gravlee, G. C. (1968) "Flood Surge on the Rubicon River, California - Hydrology, Hydraulics and Boulder Transport", U.S. Geological Survey Professional Paper 422-M.

USGS (1986). "BIBMAST REF FILE: FRI, MAR 21 1986" U.S. Geological Survey, Carson City District Office.

US West Optical (1988), "HYDRODATA Users's Manual, USGS Daily and Peak Values, Version 2.0", U S West Optical, Denver, Colorado.

Water Engineering and Technology, Inc. (1989). "Draft Report, Geomorphic Analysis of Truckee River from RM 56 to RM 43." U.S. Army Corps of Engineers, Sacramento District.

Wiberg, P. L. and Smith, J. D. (1987). "Calculations of the Critical Shear Stress for Motion of Heterogenous Sediments." Water Resources Research, Vol. 23, No. 8, pg. 1471-1480.

Wolman, M. G. (1954). "A method of sampling coarse river bed materials", American Geophysical Union, Transactions, Vol. 35, pg. 951-956. 


\section{Table 1}

Sampled Suspended Sediment Concentration From USGS Data Base for the Truckee River in the Study Area

\begin{tabular}{||l|l|l||}
\hline \multicolumn{3}{|c|}{ Truckee River near Sparks, Nevada USGS Gage No. 10348200 } \\
\hline \hline Date & Flow Rate, cfs & Concentration, mg/ \\
\hline \hline Fob. 5, 1980 & 346 & 26 \\
\hline Feb. 28, 1980 & 790 & 23 \\
\hline Mar. 12, 1980 & 533 & 14 \\
\hline Mar. 20, 1980 & 480 & 14 \\
\hline Apr. 4, 1980 & 479 & 5 \\
\hline Apr. 10, 1980 & 563 & 9 \\
\hline \hline & 1600 & 18 \\
\hline \hline May 9, 1979 & 7500 & 950 \\
\hline Dec. 20, 1981 & 5500 & 884 \\
\hline Mar. 13, 1983 & & \\
\hline
\end{tabular}

\section{Table 2}

Sampled suspended sediment concentration, Truckee River at McCarran Boulevard

\begin{tabular}{||l|l|l||}
\hline \hline Date & Flow Rate, cfs & Concentration, mg/ \\
\hline \hline 17 Dec 1985 & 347 & 5 \\
\hline 21 Jan 1986 & 682 & 9 \\
\hline 20 Feb 1986 & $14000^{1}$ & 1345 \\
\hline 25 Mar 1986 & $3430^{1}$ & 1407 \\
\hline 15 Apr 1986 & 2699 & 93 \\
\hline 5 May 1986 & 2814 & 57 \\
\hline 12 May 1986 & 2636 & 22 \\
\hline 21 May 1986 & 2407 & 32 \\
\hline 10 Jun 1986 & 1266 & 31 \\
\hline 7 Jul 1986 & 628 & 32 \\
\hline \hline 1Estimated flow rate from Truckee River at Reno USGS stream gage records. \\
\hline
\end{tabular}




\begin{tabular}{|l|l|l|l||}
\hline \multicolumn{4}{|l||}{$\begin{array}{l}\text { Table 3 } \\
\text { Equilibrium Reach Bed Load by Grain Size, Tons/Day }\end{array}$} \\
\hline \hline Sediment Material & $1,000 \mathrm{cfs}$ & 10,000 cfs & $30,000 \mathrm{cfs}$ \\
\hline \hline VFS & 9.03 & 147. & 1210. \\
\hline FS & 9.03 & 128. & 990. \\
\hline MS & 5.16 & 128. & 660. \\
\hline CS & 133. & 768. & 2310. \\
\hline VCS & 129. & 736. & 2310. \\
\hline VFG & 94.6 & 704. & 2090. \\
\hline FG & 55.9 & 544. & 1870. \\
\hline MG & 16.8 & 352. & 1540. \\
\hline CG & $3.44\left(10^{-1}\right)$ & 48.0 & 770. \\
\hline VCG & $8.17\left(10^{-2}\right)$ & 12.8 & 55.0 \\
\hline SC & $2.15\left(10^{-2}\right)$ & 1.60 & 27.5 \\
\hline LC & $1.72\left(10^{-2}\right)$ & 1.28 & 22.0 \\
\hline SB & $4.30\left(10^{-3}\right)$ & $3.20\left(10^{-1}\right)$ & 5.50 \\
\hline
\end{tabular}

\begin{tabular}{|l|l|l|l||}
\hline \multicolumn{5}{|l|}{\begin{tabular}{l} 
Table 4 Adjusted Bed Load by Grain Size, Tons/Day \\
\hline \hline Sediment Material
\end{tabular}} & $1,000 \mathrm{cts}$ & $10,000 \mathrm{cts}$ & $30,000 \mathrm{cfs}$ \\
\hline \hline VFS & 1.57 & 24.5 & 183. \\
\hline FS & 1.43 & 21.3 & 146. \\
\hline MS & 0.71 & 21.3 & 110. \\
\hline CS & 44.3 & 256. & 770. \\
\hline VCS & 42.9 & 245. & 770. \\
\hline VFG & 31.5 & 234. & 696. \\
\hline FG & 18.6 & 181. & 623. \\
\hline MG & 5.58 & 117. & 513. \\
\hline CG & 0.11 & 16. & 0257. \\
\hline VCG & $2.71\left(10^{-2}\right)$ & 4.26 & 18.3 \\
\hline & $7.15\left(10^{-3}\right)$ & 0.53 & 9.17 \\
\hline LC & $5.72\left(10^{-3}\right)$ & 0.43 & 7.33 \\
\hline SB & $1.43\left(10^{-3}\right)$ & 0.11 & 1.83 \\
\hline
\end{tabular}




\begin{tabular}{|c|c|c|c|c|}
\hline Location & Sand Load & Gravel Load & Cobble Load & Total Bed load \\
\hline RM 53.1 & 28,960 & 22,040 & 17 & 51,000 \\
\hline RM 47.3 & 24,420 & 20,130 & 0 & 44,550 \\
\hline RM 44.4 & 14,150 & 2,690 & 0 & 16,840 \\
\hline RM 43.9 & 12,820 & 1,940 & 0 & 14,760 \\
\hline
\end{tabular}




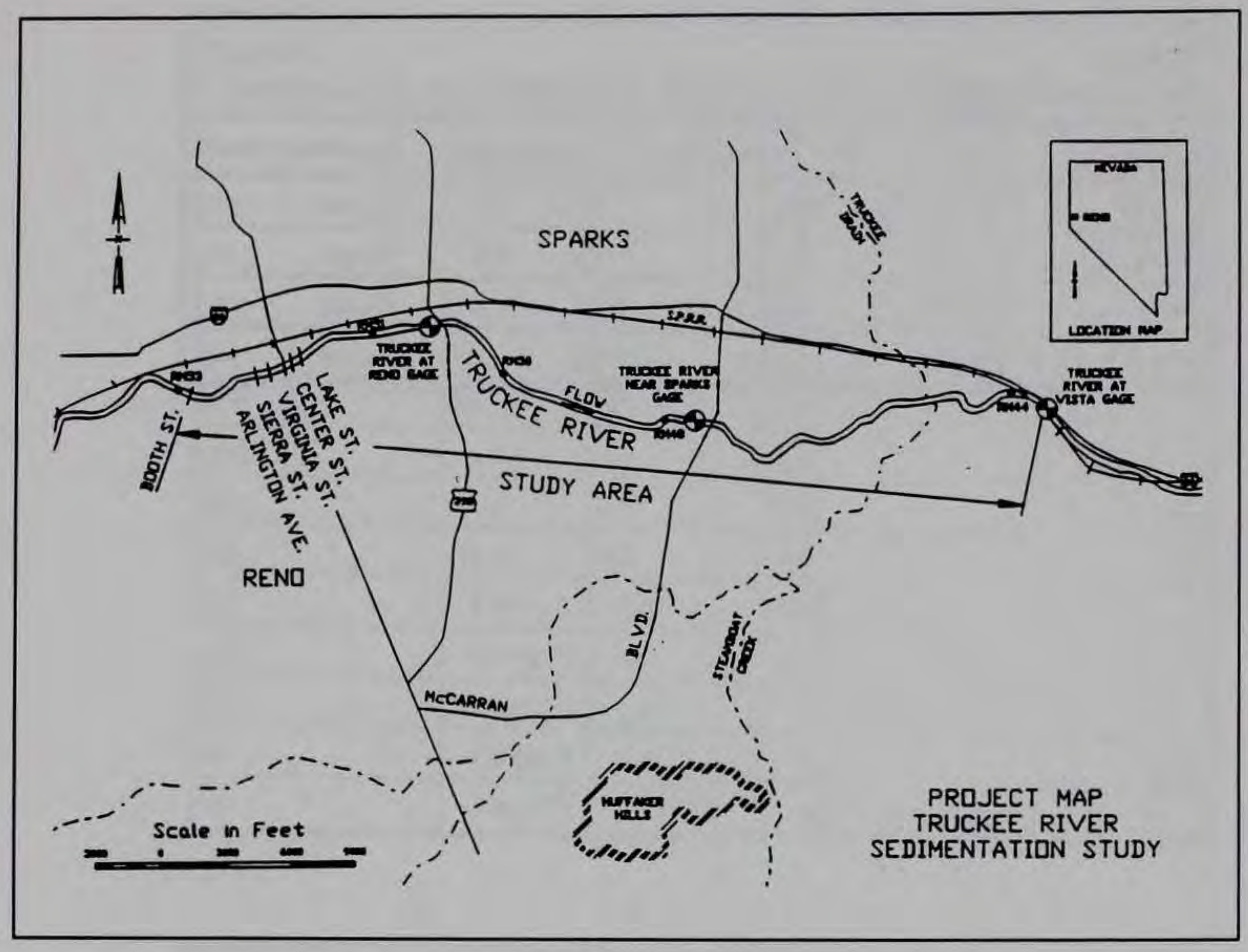

Figure 1. Study area

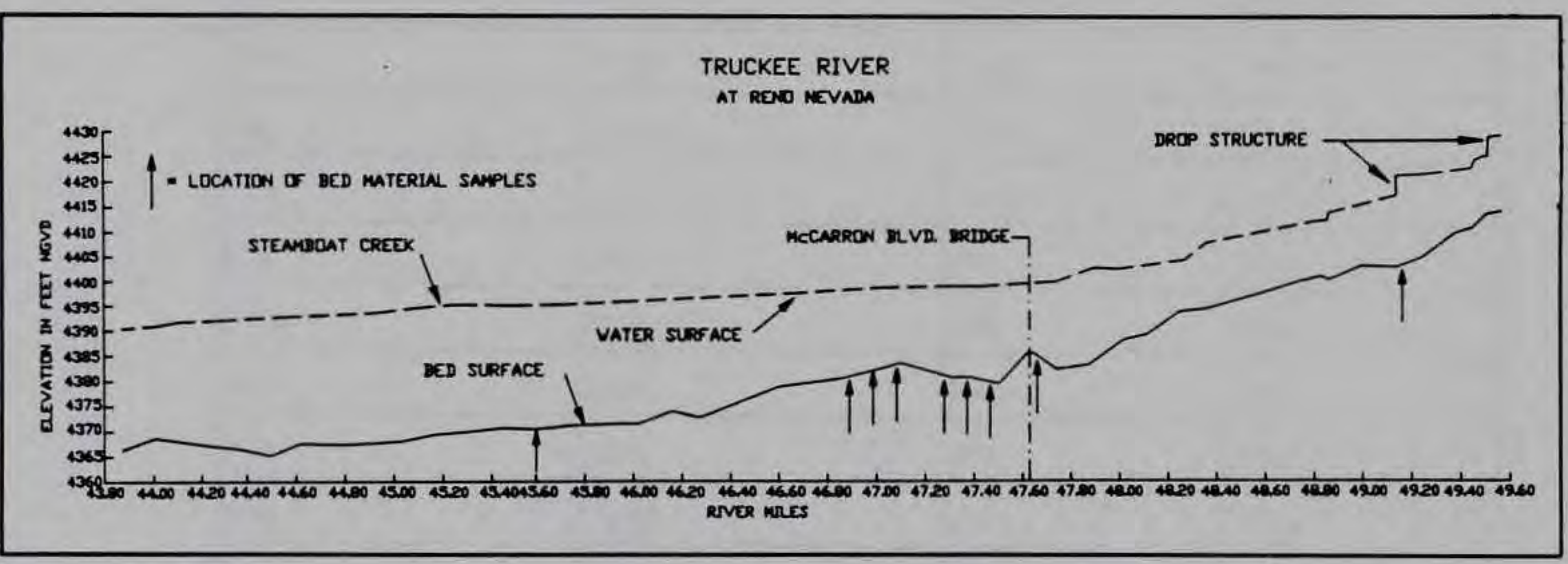

Figure 2. Measured 1975 channel thalweg and computed water surface profile (discharge = $25,000 \mathrm{cfs}), \mathrm{RM} 43.8$ to 49.6 


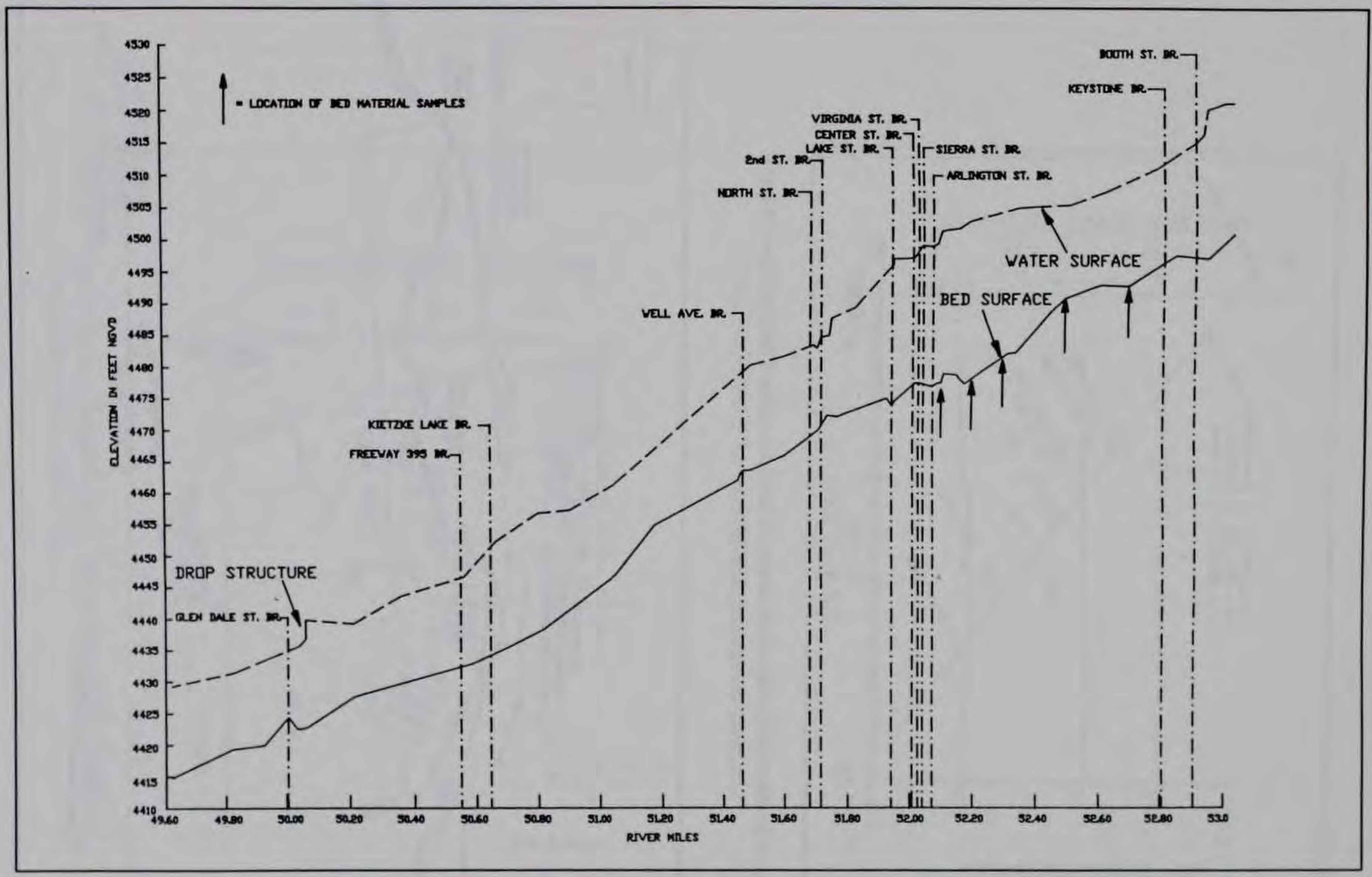

Figure 3. Measured 1975 channel thalweg and computed water surface profile (discharge $=25,000 \mathrm{cfs}$ ), RM 49.6 to 53.0 


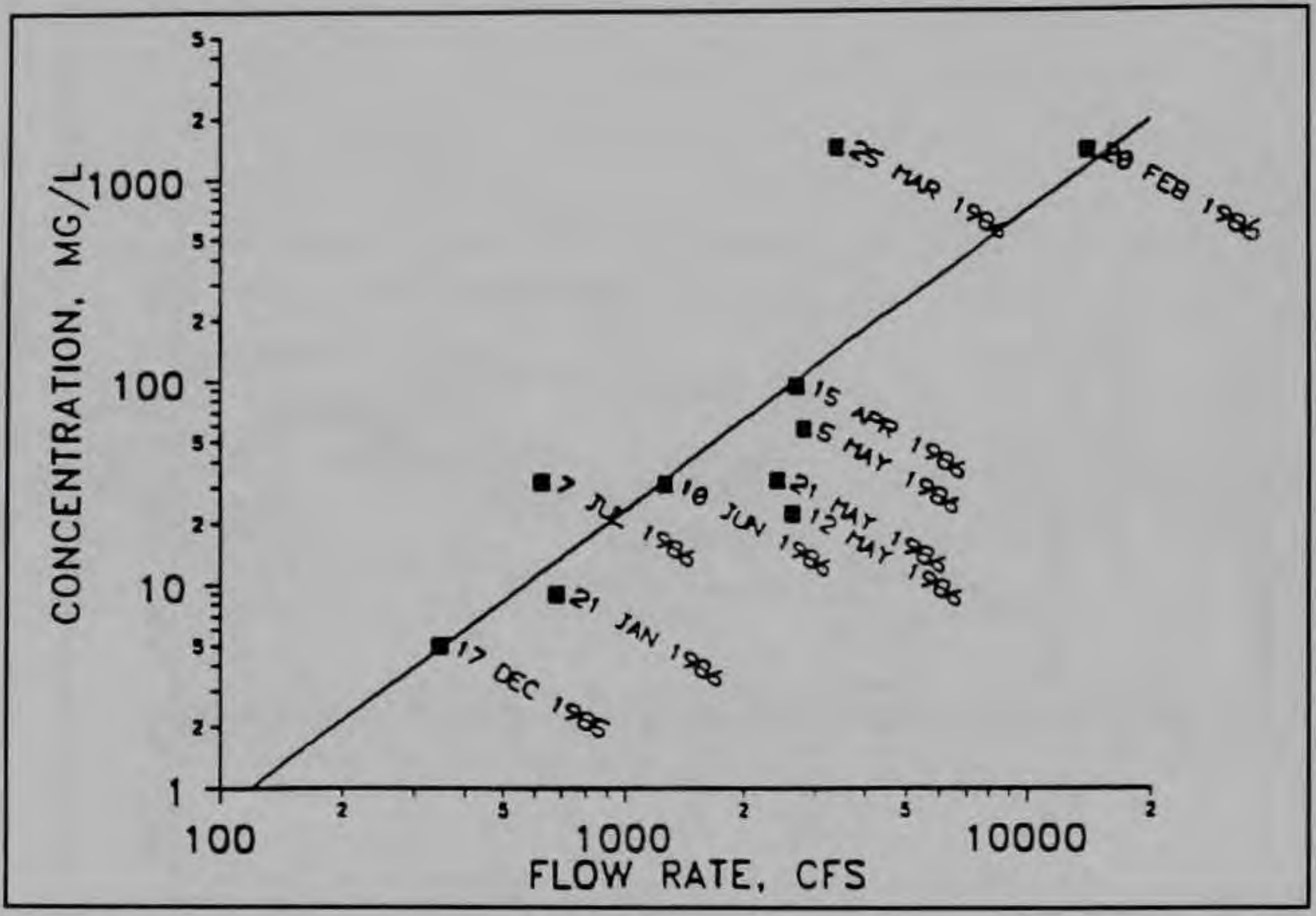

Figure 4. Measured suspended sediment concentration, Truckee River at McCarran Boulevard, RM 47.7

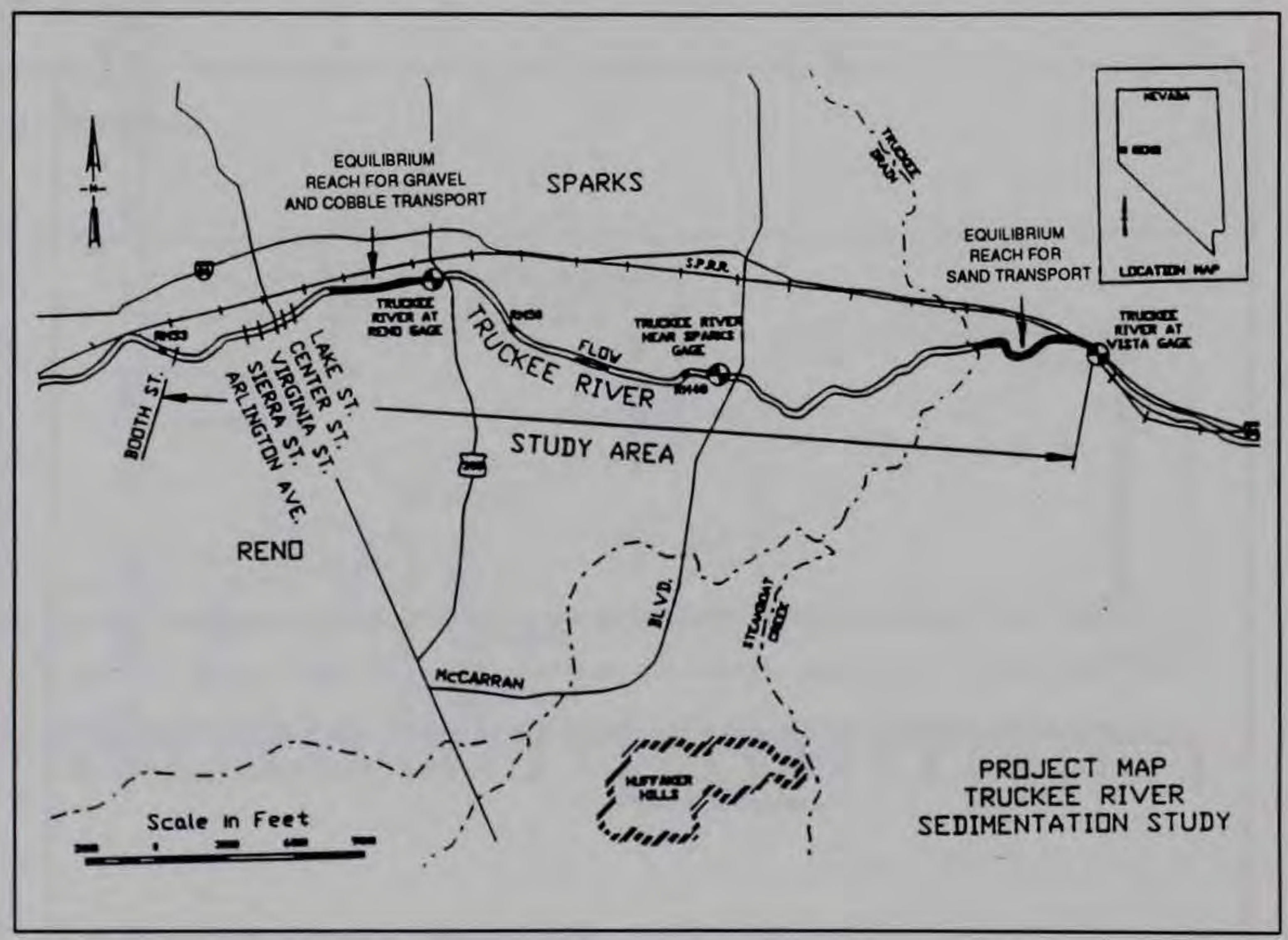

Figure 5. Location of "Equilibrium Reach" within study area 


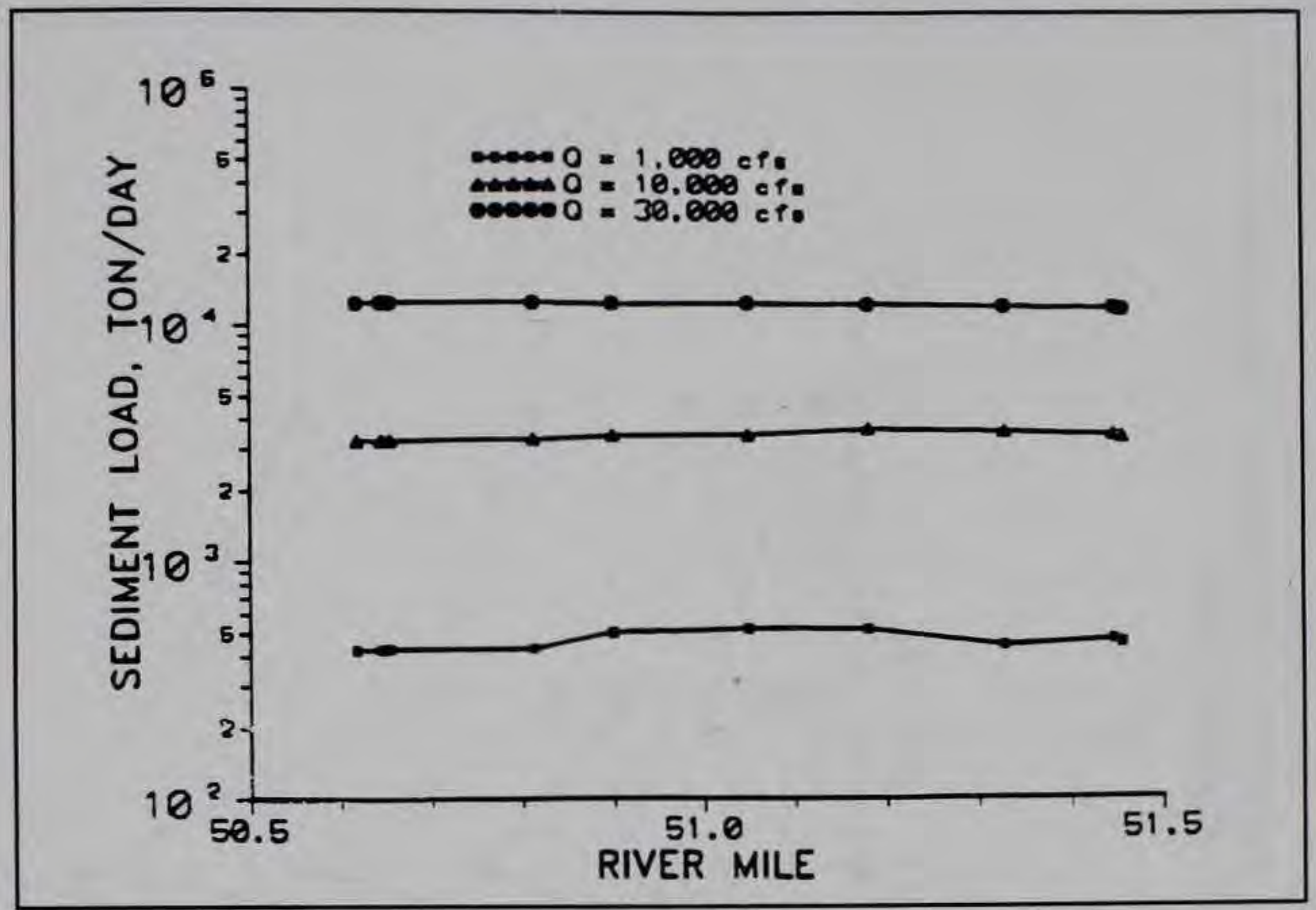

Figure 6. Computed transport of bed material for the Equilibrium Reach, using the Meyer-Peter and Muller transport equation

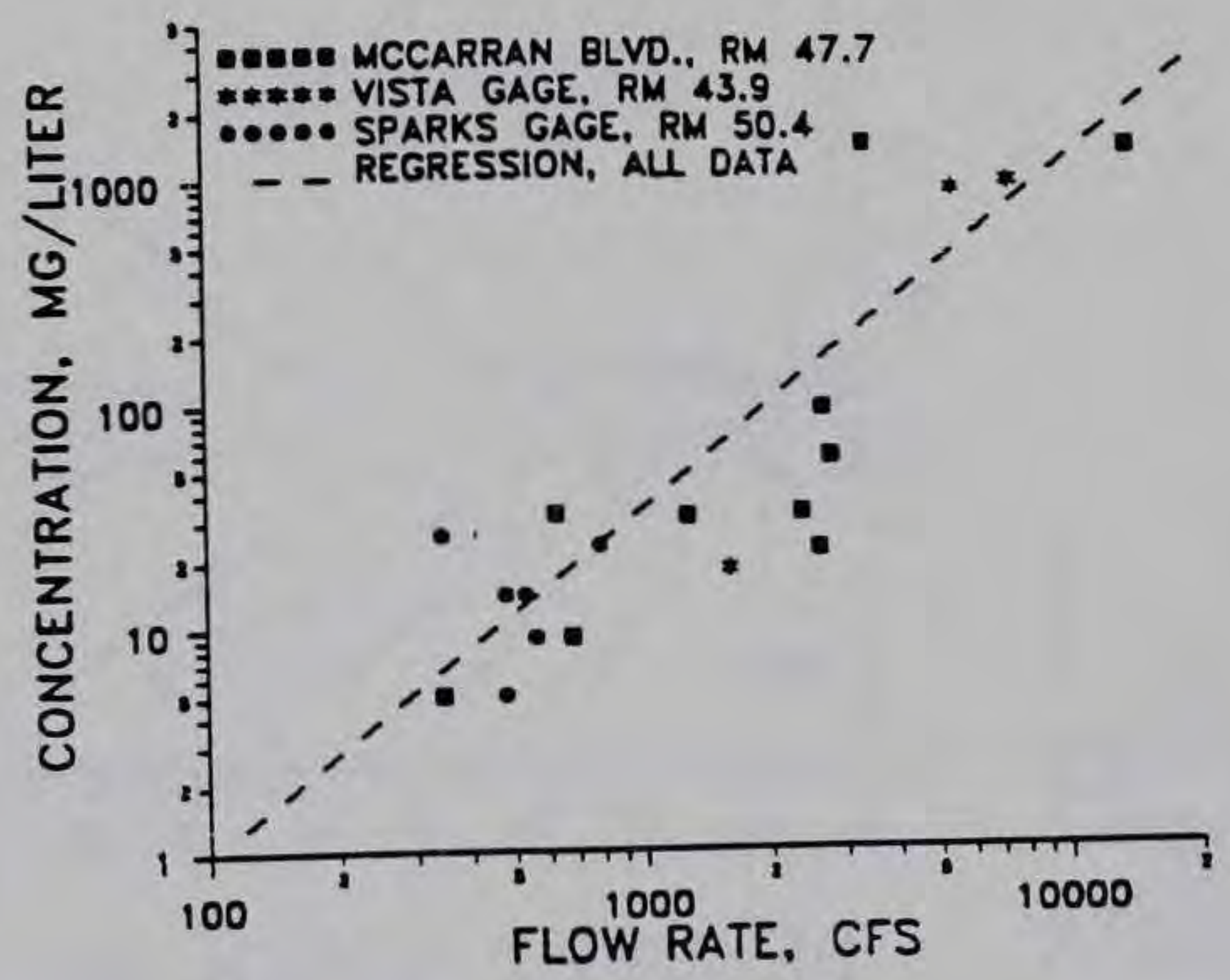

Figure 7. Comparison of measured suspended sediment concentrations, Truckee River RM 43.9 to 50.4 


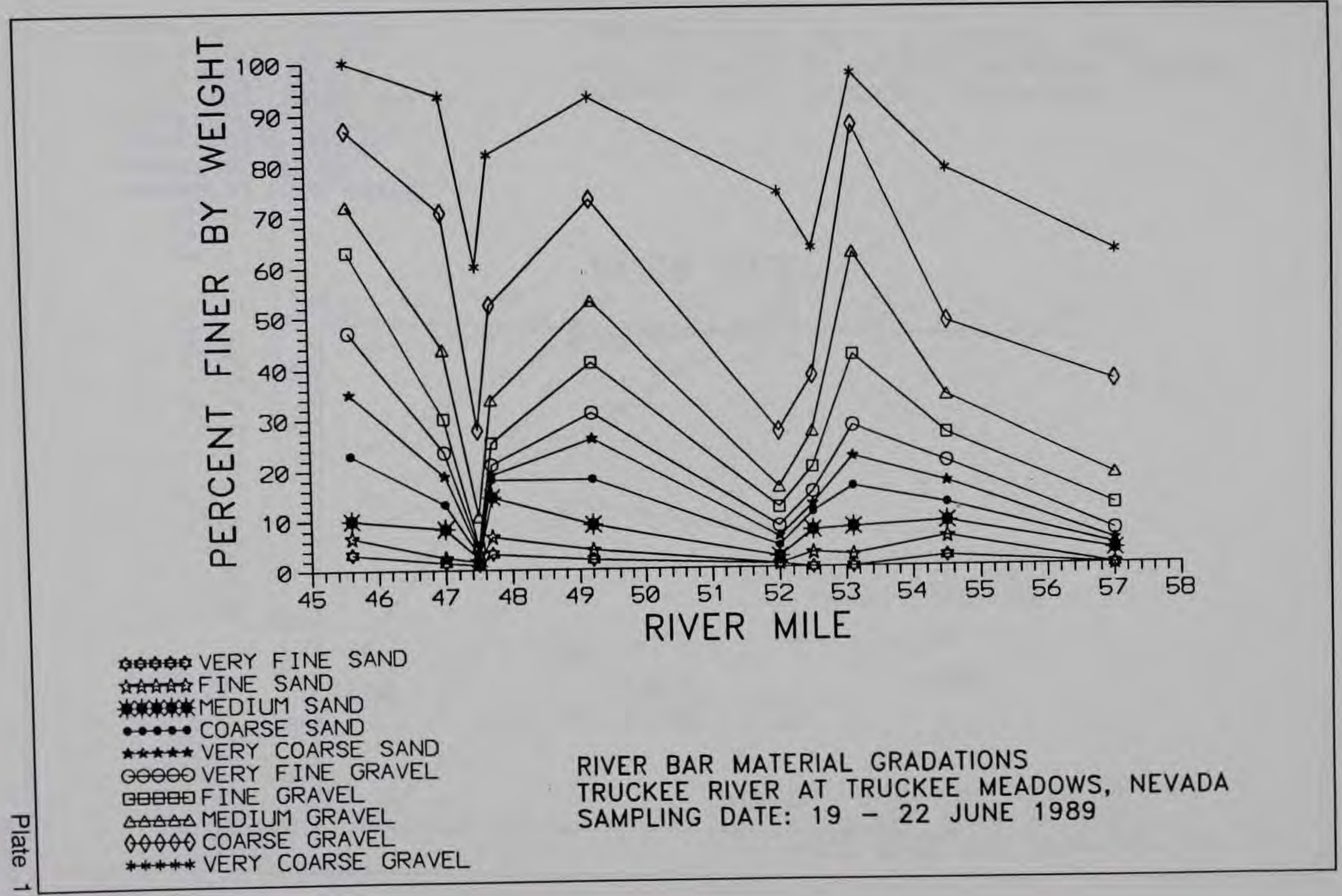




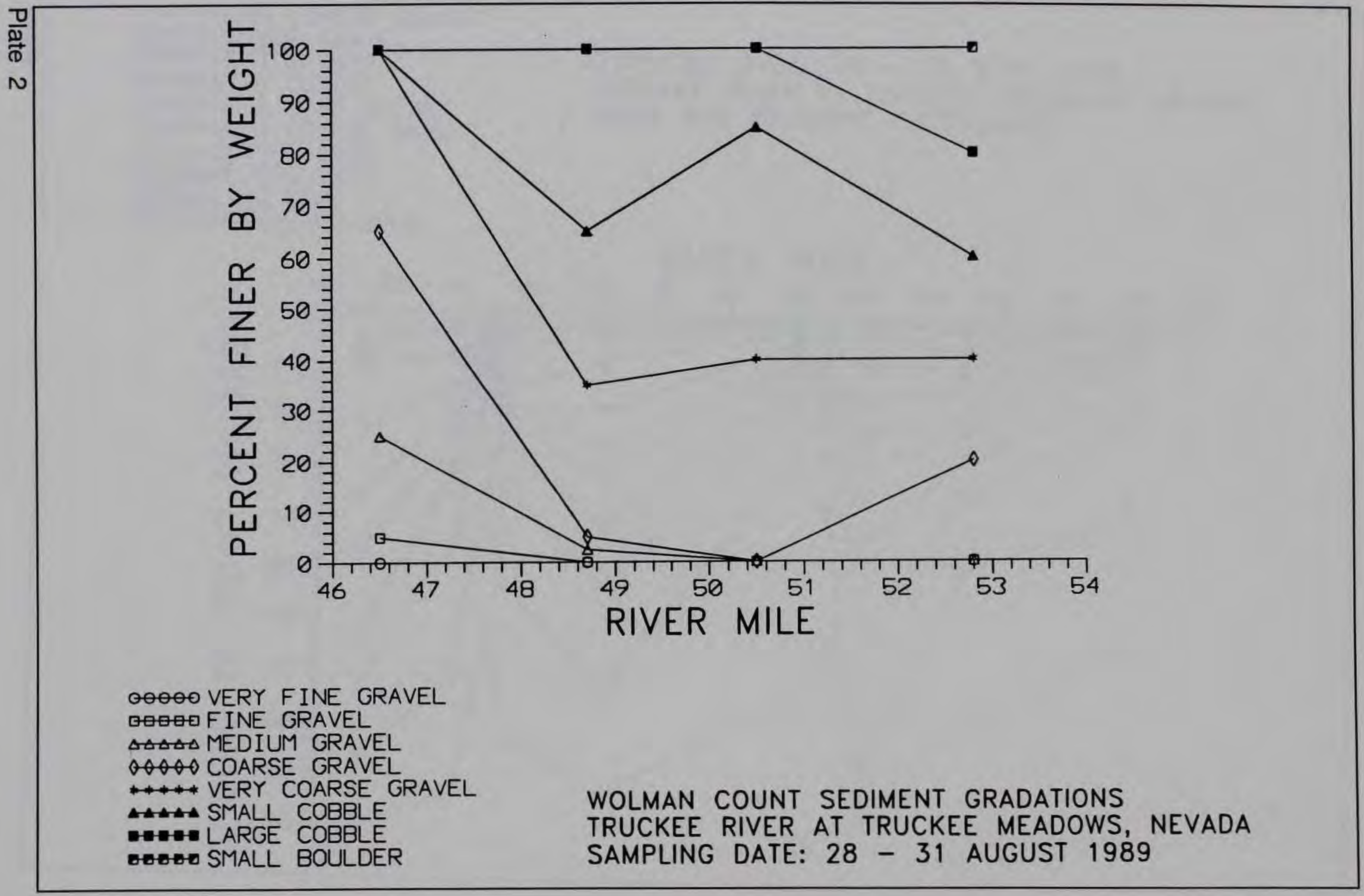




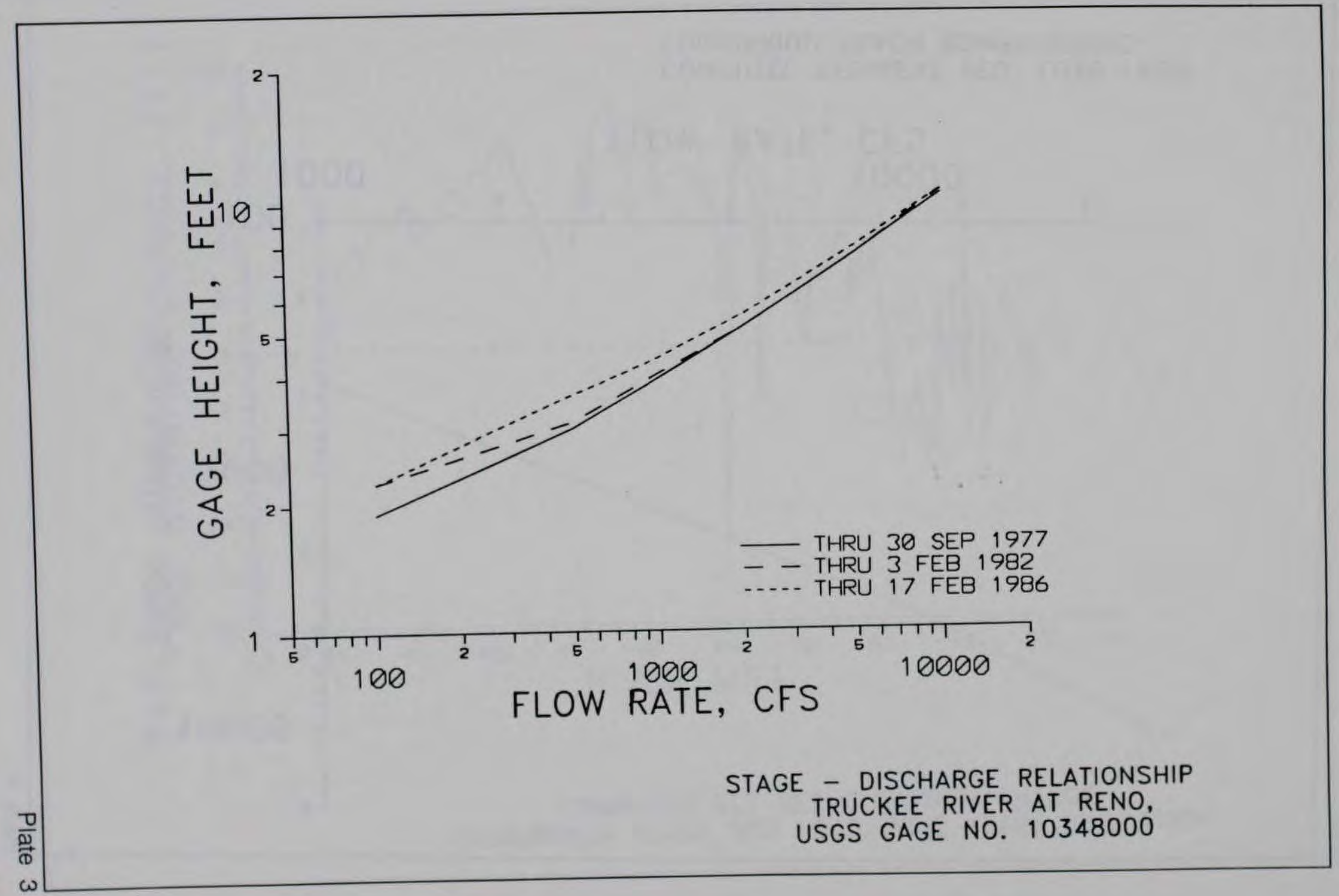




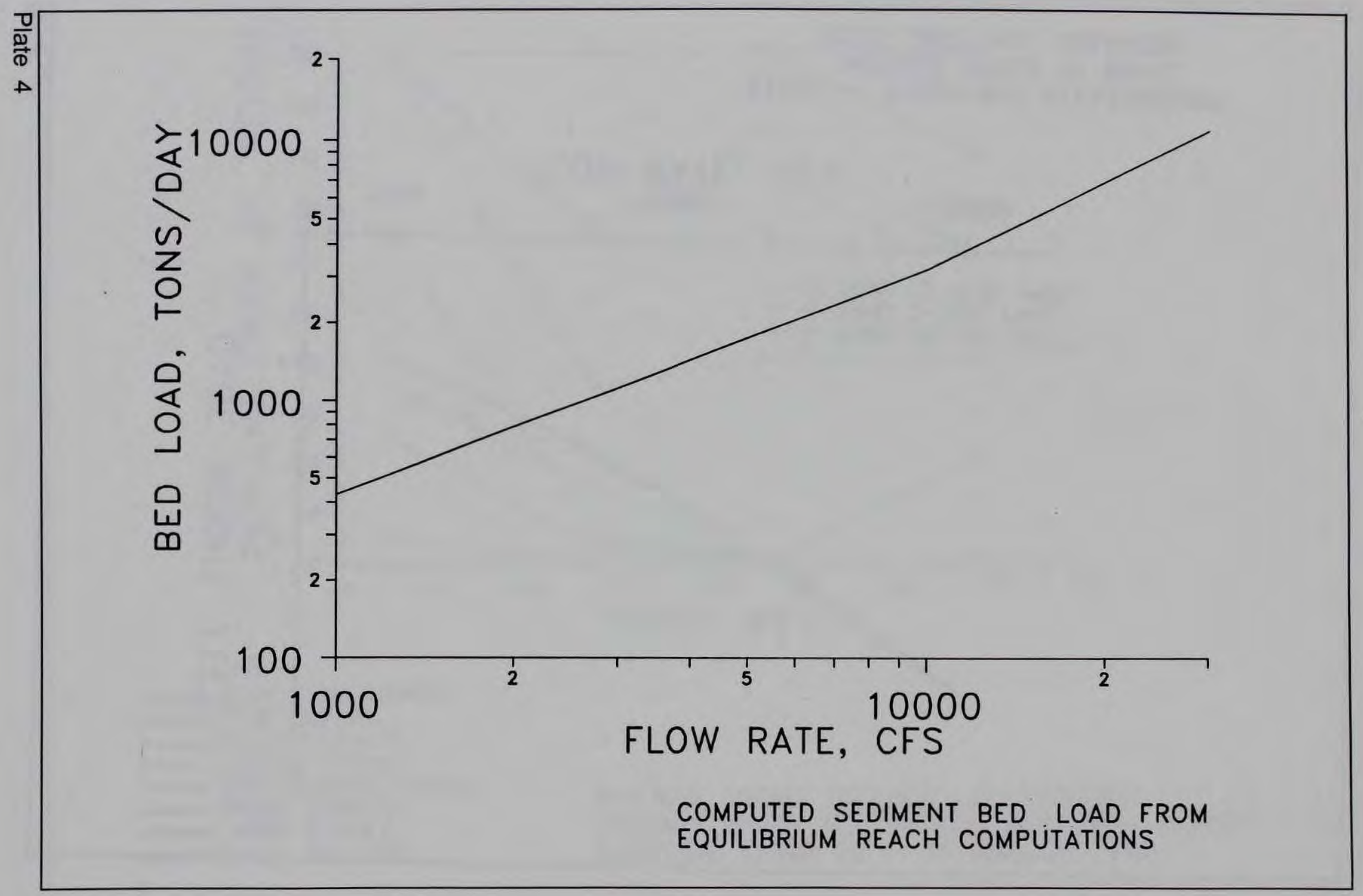




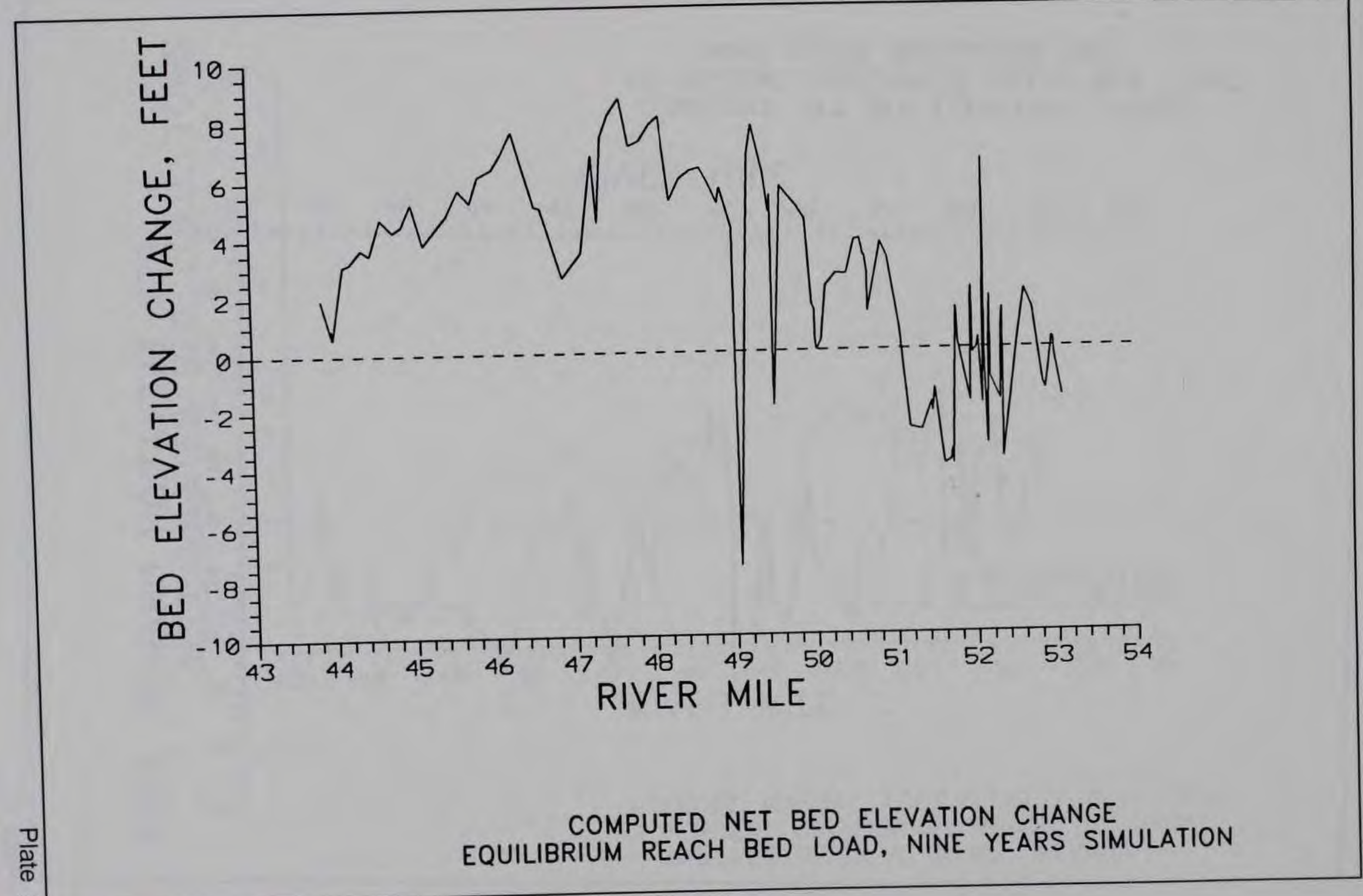




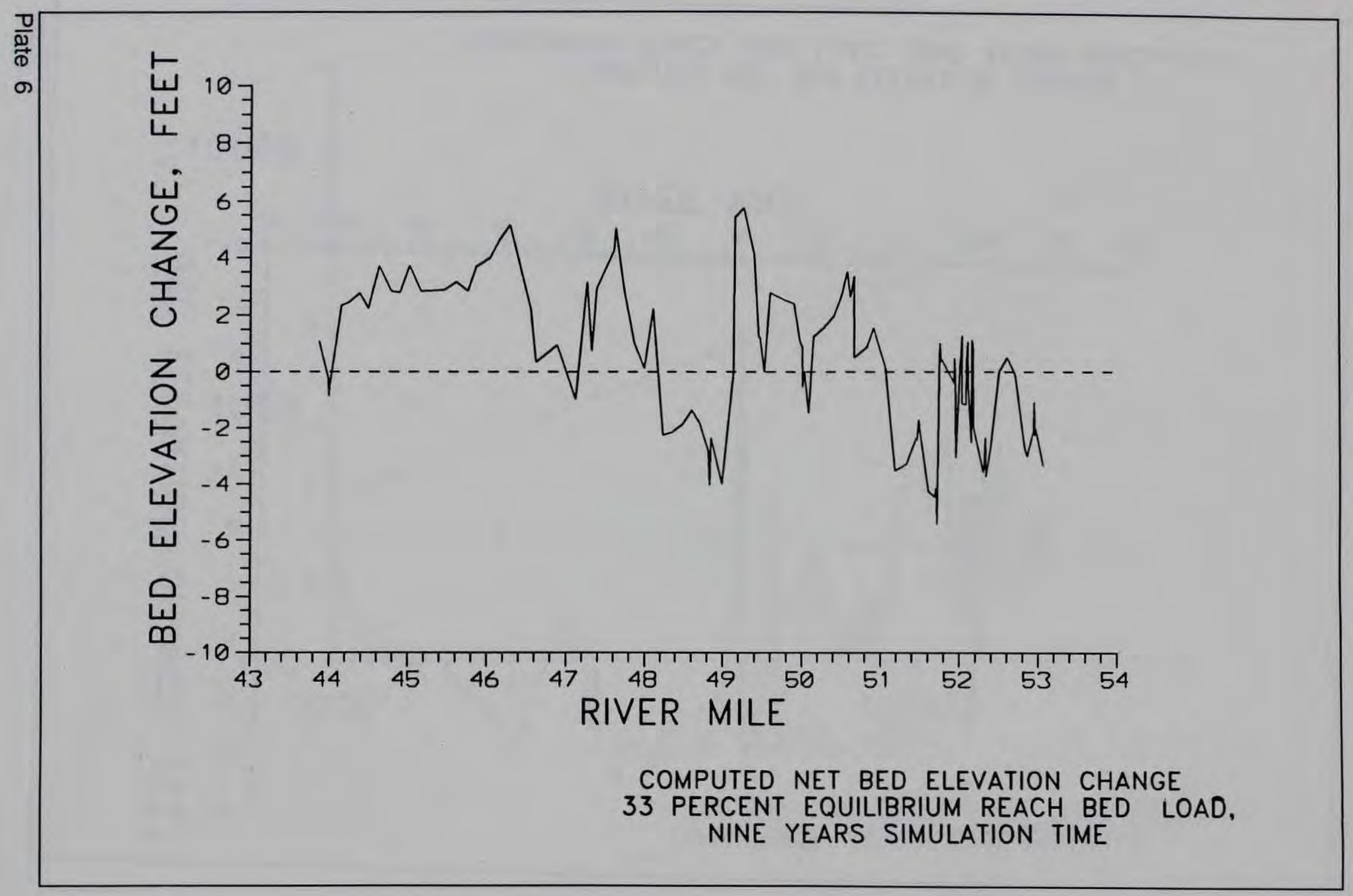




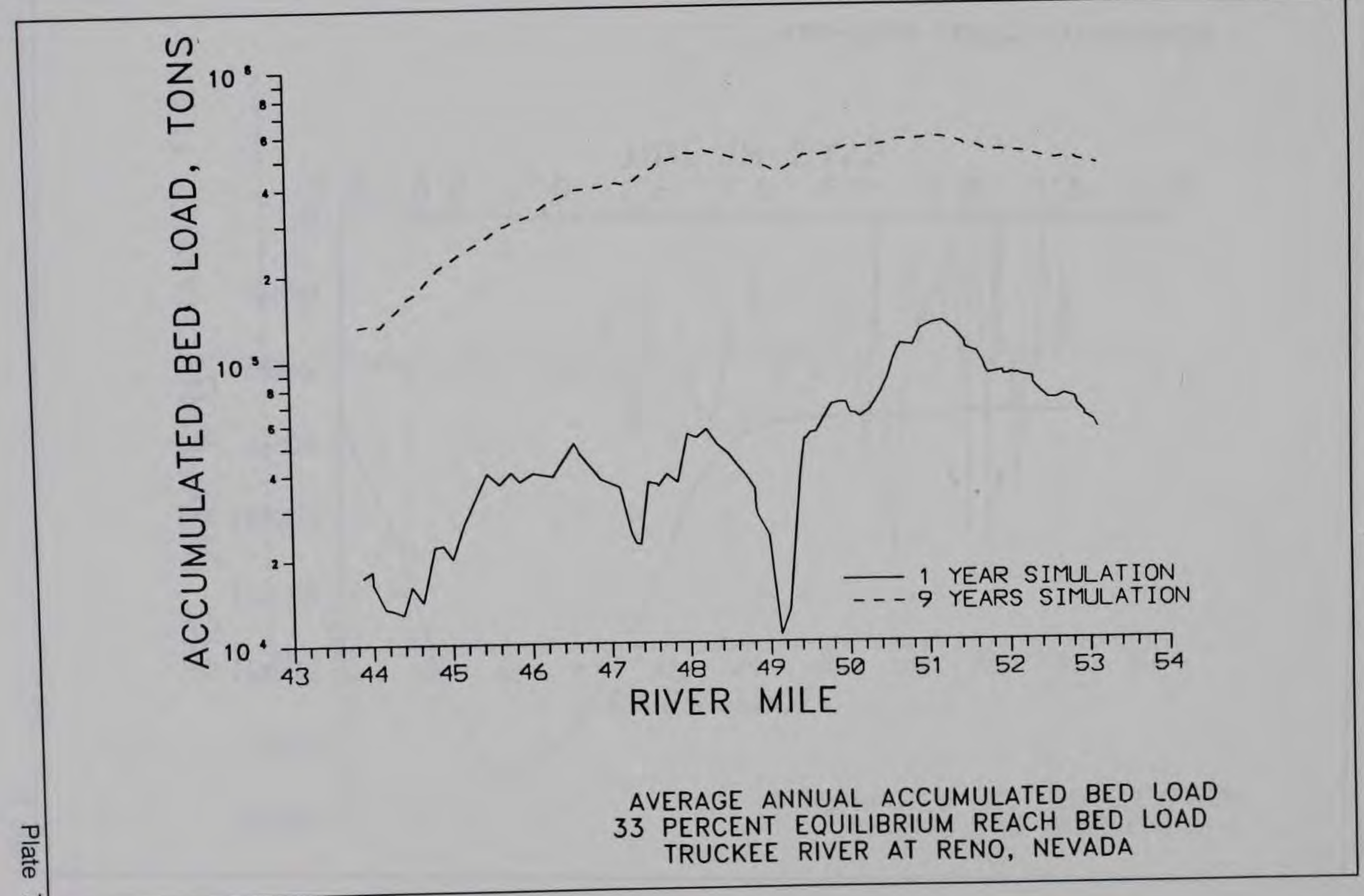




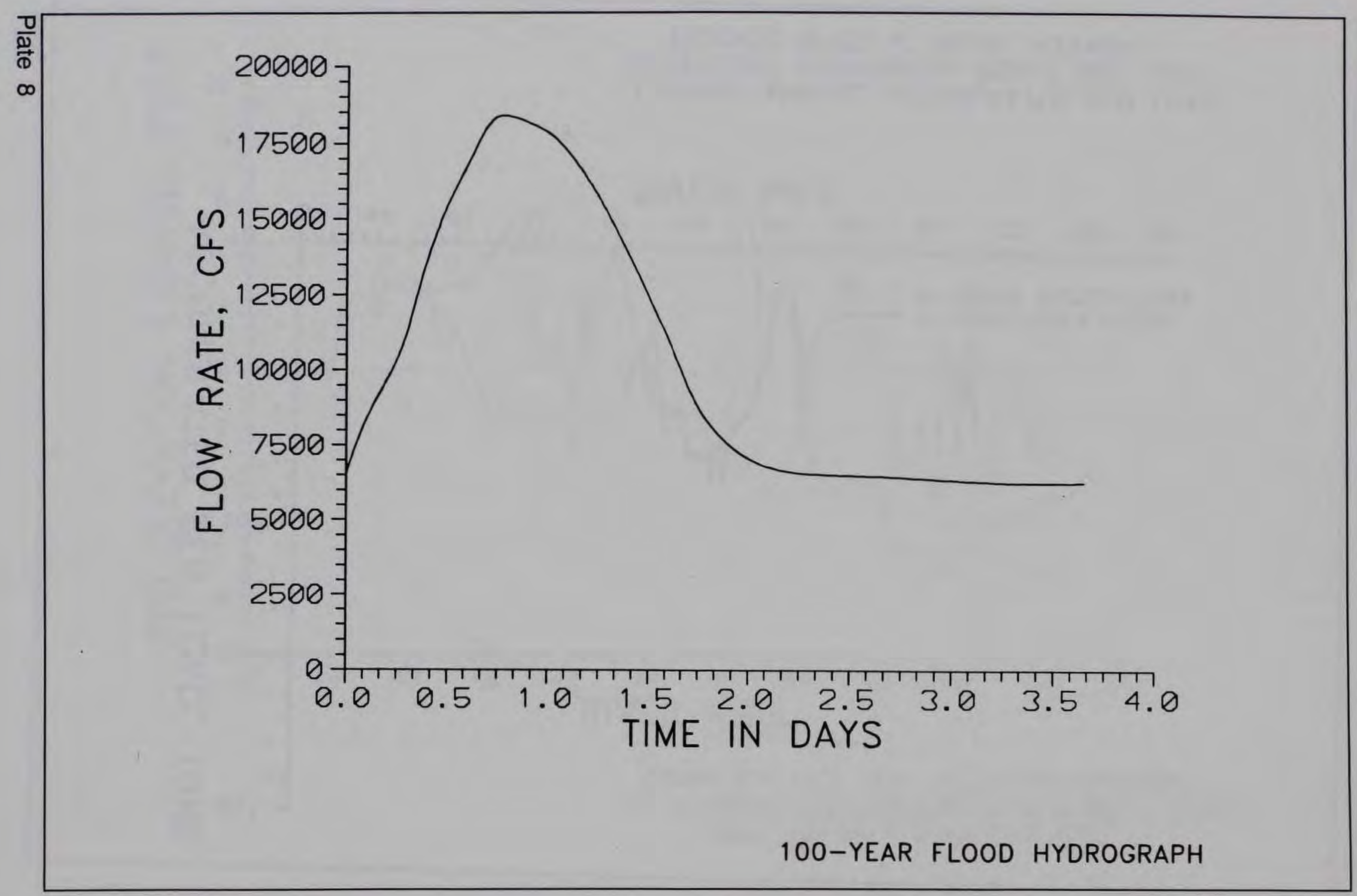




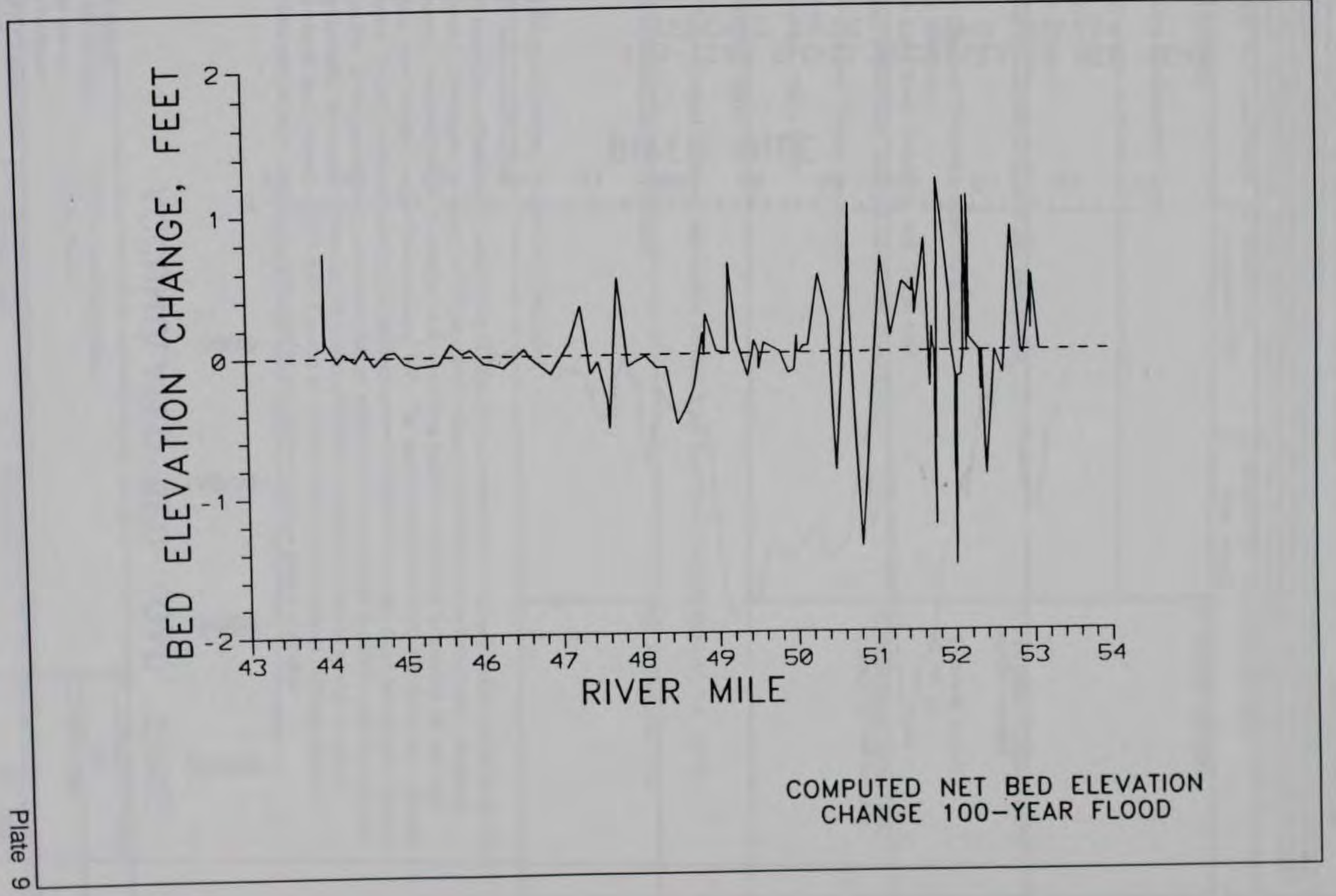




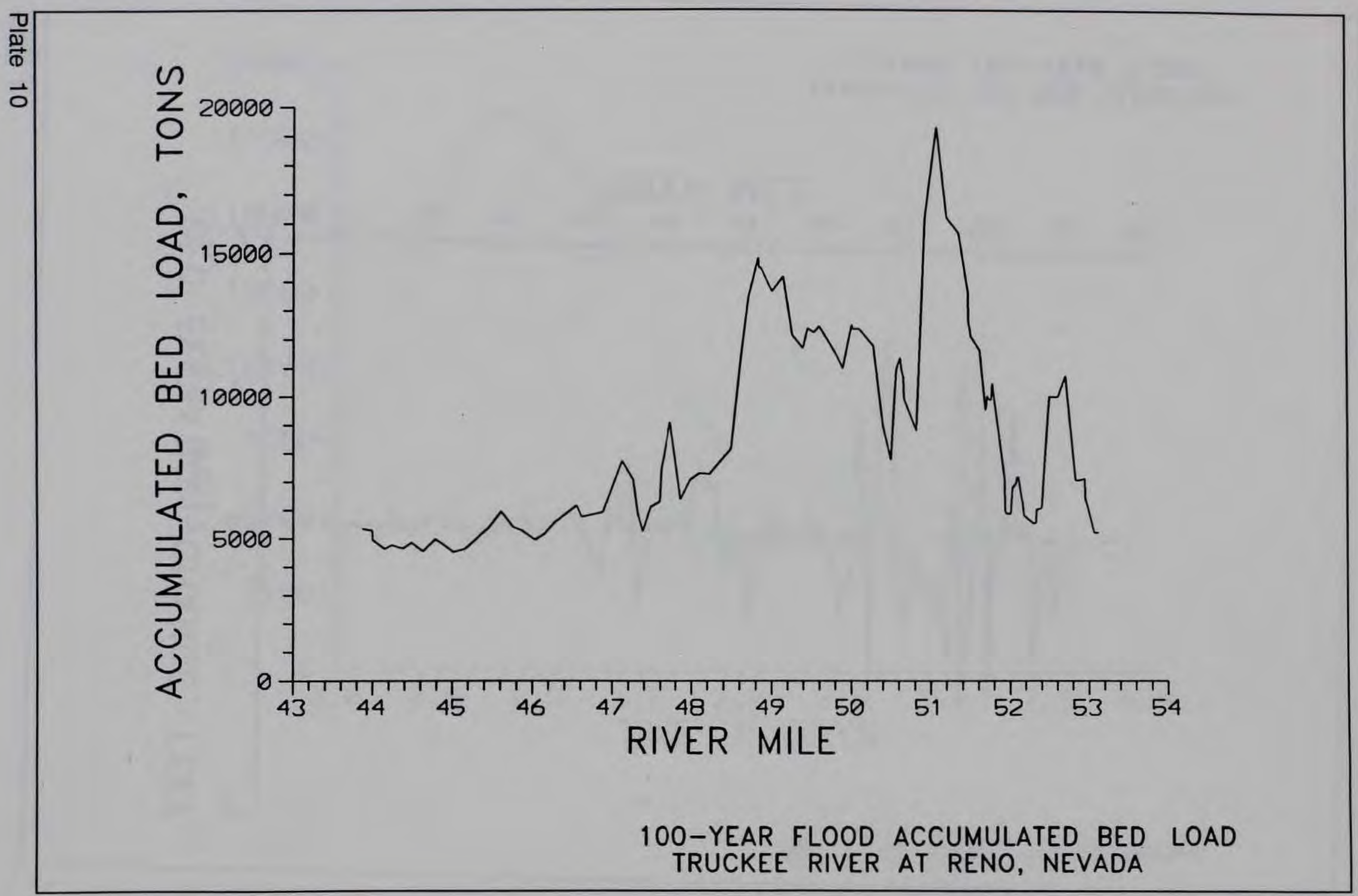




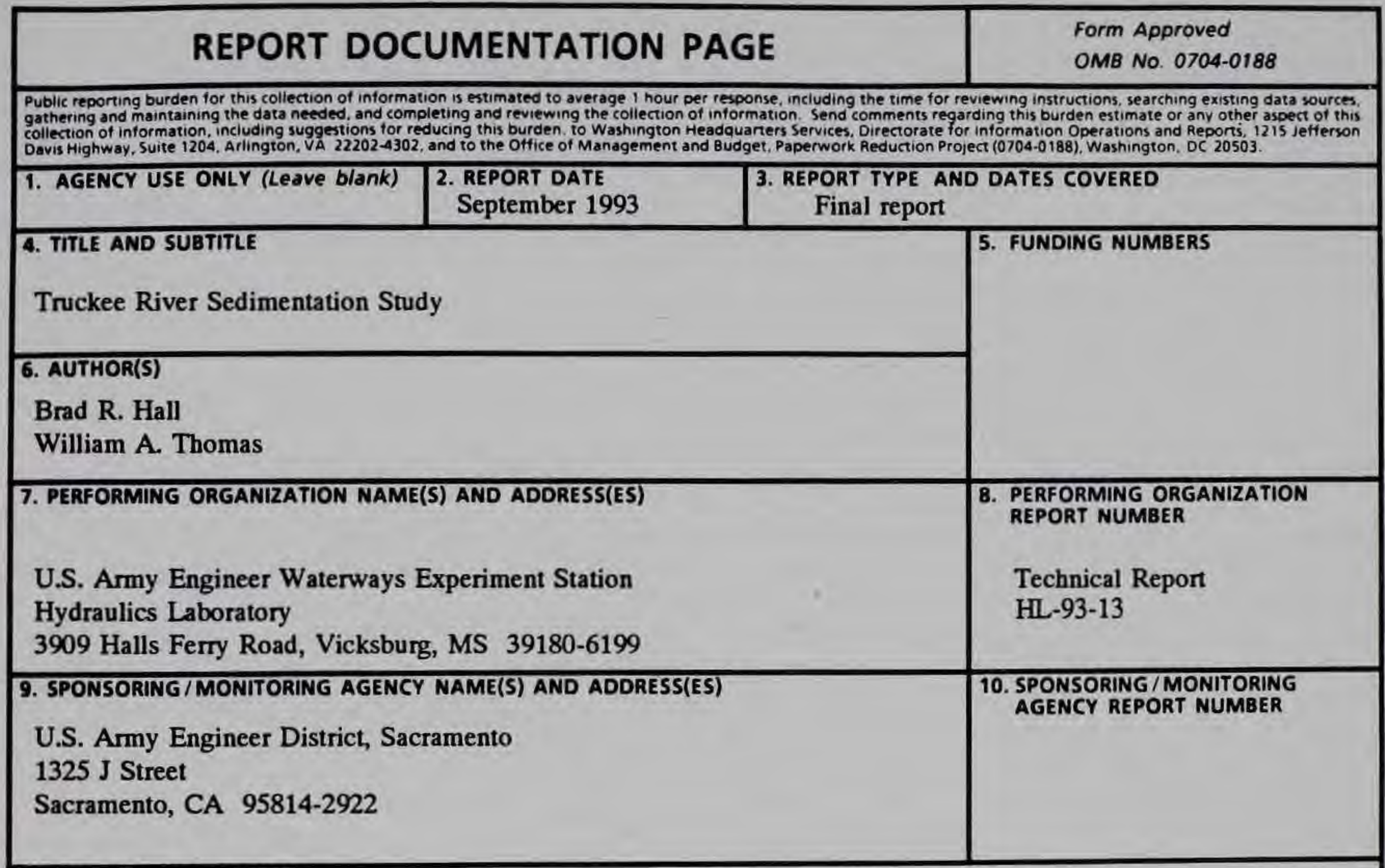

\section{SUPPLEMENTARY NOTES}

Available from National Technical Information Service, 5285 Port Royal Road, Springfield, VA 22161.

\begin{tabular}{|l|l}
\hline 12a. DISTRIBUTION/AVAILABILITY STATEMENT & 12b. DISTRIBUTION CODE
\end{tabular}

Approved for public release; distribution is unlimited.

\section{ABSTRACT (Maximum 200 words)}

A numerical sedimentation model study (TABS-1) was conducted to develop a sedimentation model that could be used to investigate the impact of Truckee River channel modification on sedimentation. Sediment transport theory was combined with evidence developed from field reconnaissance to quantify the bed load inflow rating curve for the Truckee River at Reno, NV. The existing condition TABS-1 sedimentation analysis of the Truckee River indicates that channel adjustment occurs throughout the design flood hydrograph. Due to sediment inflow to the project reach, continued channel adjustment for the project condition could be expected. In order to quantify the channel adjustment for project conditions, a sediment transport model for project conditions should be developed. The TABS- 1 model developed in this study to address existing condition sediment transport through the project reach could be modified to simulate project conditions.

\begin{tabular}{|c|c|c|c|}
\hline $\begin{array}{l}\text { 14. SUBJECT TERMS } \\
\text { Channel sedimentation }\end{array}$ & \multirow{2}{*}{\multicolumn{2}{|c|}{$\begin{array}{l}\text { TABS- } 1 \text { modeling system } \\
\text { Truckee River }\end{array}$}} & $\begin{array}{l}\text { 15. NUMBER OF PAGES } \\
46\end{array}$ \\
\hline $\begin{array}{l}\text { Numerical model } \\
\text { Sediment transport } \\
\end{array}$ & & & 16. PRICE CODE \\
\hline $\begin{array}{l}\text { 17. SECURITY CLASSIFICATION } \\
\text { OF REPORT } \\
\text { UNCLASSIFIED }\end{array}$ & $\begin{array}{l}\text { 18. SECURITY CLASSIFICATION } \\
\text { OF THIS PAGE } \\
\text { UNCLASSIFIED }\end{array}$ & $\begin{array}{l}\text { 19. SECURITY CLASSIFICATION } \\
\text { OF ABSTRACT }\end{array}$ & 20. LIMITATION OF ABSTRACT \\
\hline NSN 7540-01-280-5500 & & & $\begin{array}{l}\text { andard Form } 298(\operatorname{Rev} 2-89) \\
\text { scribed by ANSI Std } 239-18 \\
3-102\end{array}$ \\
\hline
\end{tabular}

